\title{
State Politics in Yemen: Antinomies of Nation and State
}

\author{
Serge D. Elie*
}

Independent Scholar

\begin{abstract}
This article offers a synoptic narrative informed by a political anthropology that retraces the historical genesis of modern nation-state formation in Yemen, and describes the mechanisms of its reproduction as an explanatory prelude to the ultimate political implosion of both the Yemeni state and the national polity in the aftermath of the Arab Spring. The article elucidates the trajectory of the state's formation through the following tasks: First, it examines the catalytic factors and forces that structured the relations between the Yemeni state and the national polity, and systematically reviews the institutional and agential consequences in the form of endemic antinomies of governance, which resulted in the permanent structural disarticulation between state and nation. Second, it undertakes a history-embedded analysis of the state's adoption of an existential politics that led to a hybrid political system of elite patronage and mass clientelism. Third, it performs a structural anatomy of the state formation process that culminated in a cabalistic corporatist state exercising a consociational domination over a socio-geographically fragmented polity. And fourth, it assesses the impacts of Yemen's Arab Spring on the likely configuration of the nation-state nexus given the re-emergence of centrifugal forces that are threatening to sunder the nation into multiple regional polities.
\end{abstract}

Keywords: Corporatism, Mesography, Nationalism, Political anthropology, Regionalism.

\section{INTRODUCTION: THE DISARTICULATION OF NATION AND STATE}

The nation is the imagined community of the State $[1$, p. 406]

Yemen's entry into political modernity was inaugurated with the 1962 revolution in the north, while south Yemen was under British rule until 1967. That revolution promised a normative reorientation of the state's institutional practices and of the nation's political culture: From the millennial reign of a feudal theocracy ruling a status-based and hierarchically-ranked polity of subjects that was overwhelmingly rural and configured into territorially bounded fiefs led by hereditary tribal shaykhs; to a modern republican state animated by a socially radical aspiration to rid Yemen of its premodern social order and to replace it with formal and functioning administrative and representative institutions for a polity of equal citizens managed by a government of technocrats pursuing a project of societal transformation. However, the Yemeni revolution occurred in the midst of an "Arab Cold War" that began in July of 1952 with the Egyptian revolution, which overthrew the Egyptian monarchy [2]. This consolidated the rise of republican regimes in the region, which was previously dominated by feudal monarchies. This cold war unleashed an ideological struggle over the fate of the Arab world, which pitted the secular modernism of pan-Arab nationalism

"Author is an Independent Scholar. Address is P.O. Box 11756, Kuala Lumpur, Malaysia 50756;

E-mail: jds.elie11@gmail.com heralded by the revolutionary republican regime of Egypt under President 'Abd al-Nāșir's charismatic leadership regarded as a beacon of anti-imperialism, against the religious traditionalism of pan-Islamism defended by the conservative monarchy of Saudi Arabia under King Fayșal perceived as a vassal of Western imperialism. Soon after Yemen's 1962 revolution, abetted by the Egyptian example, the country became embroiled in an eight year civil war, which was the theater of a proxy war between the new Republican/revolutionary forces supported by Egyptian troops and the Royalist/counter-revolutionary forces of the overthrown Imamate backed by Saudi Arabia's petro dollars. At stake was whether Yemen would revert to a feudal monarchy or become a modern republic [3, 4].

The revolution of 1962 was the catalyst to modern state-building as it entailed the overthrow of an ancien régime with its feudal governing practices over a primordial polity. However, the political settlement of the civil war changed the balance of power between modernist/nationalist actors and the traditionalist /monarchic ones in favor of the latter, which determined the nature of nation-building in Yemen. Indeed, according to Wimmer and Feinstein [5], as a rule, "The balance of power between these actors determines which vision of a legitimate political order and which institutional principles will prevail" in shaping the nationbuilding process (p. 769). In North Yemen, "Rather than force a transformation of the [traditionalist] periphery to conform to the modernist centre, the outlook of the centre... [was made] to encompass 
many of the goals and values of the periphery" [6, p. 99]. This led to the sedimentation of "inertial forces" that relegated the country into a post-traditional trap: That is, an arrested societal transition that indefinitely straddles the rural and the urban and is accompanied by stagnation in its cultural, institutional and human development.

As a result, Yemen embarked on a contradictory, and ultimately dysfunctional, state and nation-building project, as the key components of such a project combined into a malignant synergy: (a) the effective bureaucratic incorporation of the national territory was disabled by weak institutional development through, initially by default and subsequently by design, the nonmodernization of the state apparatus; (b) the formation of the national polity through the integration of the constellation of regionally demarcated tribal polities was hindered by the impoverished symbolic resources of the state's political elite (soldiers and tribal shaykhs), which deprived them of cultural legitimacy and political hegemony (as was the case with the Imamate's class of sāda); (c) the state's political socialization of a modern national polity was undermined by the initial prohibition, and subsequent misuse, of the party mechanism; and (d) the ideological mobilization of the population through the use of nationalism as an instrument for the formation of a collective political will and a shared national identity failed due to its expedient invocation as a mere rhetorical stratagem. The legacy was a permanent structural disarticulation between the nation and the state that not only fomented endemic antinomies of governance, but also prevented the state from achieving hegemonic status over the national territory. This condemned state leaders to a permanent legitimation crisis, which forced them to resort to expedient policy-making through what I call the state's existential politics.

The synoptic narrative that follows provides an overview of the historical constitution of the Yemeni nation-state and of its contemporary operational modality. It elucidates the inaugural vectors of the state's institutional maldevelopment and their structuring effects on nation-state formation. These led to the state's adoption of governance practices that relied on the deliberate fomentation and tactical containment of centrifugal forces in the national polity. The different stages of modern state formation in Yemen are identified as the effects of a historical pathdependent process that culminated into the current threats to its unitary status.

\section{A MESOGRAPHIC ANALYSIS: HISTORICAL GENEALOGY AND STRUCTURAL ANATOMY}

I adopt a political anthropology approach to the study of state-society relations in Yemen. However, I avoid the epistemic pathos of disciplinary practitioners, who seem irremediably committed to the prevalent ethnocentric comparative epistemology of political anthropology; and thus are still in thrall to a colonialist ethic of inquiry. Indeed, the West-stream conception of political anthropology "is a marriage between critical theory approaches and postmodern, 'Foucauldian' emphases on power and representation, held together by the bottom-up approaches that have always defined anthropology" [7]. This "marriage" of critical theory and a postmodern perspective is animated by a hubristic "constructivist commitment" and a hegemonic "interpretivist sensibility" that license the anthropologist's exoticizing representational practices of cultural others as theoretical effigies [see 8]. Moreover, the anthropology of state-society relations is circumscribed within a Gramscian-AndersonianFoucauldian-Agambian theoretical quartet: Antonio Gramsci postulates the need for the socio-cultural hegemony of a ruling class achieved through its pedagogical functions and their polity consensus building effects, as necessary to the symbolic formation of a more sustainable legitimacy of state authority $[9,10]$. Benedict Anderson predicates a colonial capitalism-induced process of "cultural modernization" as the catalyst to nation formation that is contingent on mass literacy and the availability of printing technology for the production of the nation as an "imagined community" made up of a mass mediated collectivity of discursively constructed citizens [11]. Michel Foucault's discursive regime has bequeathed a hyper-referential conception of power as "biopower" that organizes a social formation through the "disciplinary effects" of a "synaptic regime of power" and its "capillary form of existence ... where power reaches into the very grain of individuals, touches their bodies and inserts itself into their actions and attitudes, their discourses, learning processes and everyday lives" [12, p. 39]. And lastly, Giorgio Agamben, the latest conscript in anthropology's pantheon of oracular theorists, whose dystopic vision entails a paranoid anthropology of the gulag in which the modern state is obsessed with "the paradigm of security as the normal technique of government". This eventually leads to the normalization of the concentration camp as a model of state governance the world over [13]. These theories are appropriated as the universally applicable epistemic resources of an "anthropology of the political", and are 
reflexively employed as "paradigm of government" to elucidate state praxes in the Global South [see 14-16].

Two ethnographies of state-society relations in Yemen are used to briefly illustrate the ramifications of anthropological analyses that are informed by the discipline's constructivist orientation and its decontextualizing interpretive penchant. This leads to the conception of research subjects and contexts as symbolic playgrounds for the elaboration of theoretically idiosyncratic tales from the field that parody the lived experience of cultural others: In the first, religious texts simultaneously incarnate Foucault's disciplinary biopower and Anderson's text-mediated construction of citizens in the polity-formation of an illiterate society; and in the second, Pierre Bourdieu's symbolic capital comes to the rescue of a sacked premodern elite in a modernizing state.

Brinkley Messick's ethnography, The Calligraphic State, is an articulation of the Orientalist tradition of textual exegesis and the anthropological vocation of face-to-face interaction, leading to a hybrid practice: An "ethnography of texts." He sought to offer Yemen as a counter-intuitive exemplification of how Foucault's biopower and Anderson's mass mediation are achieved through the dissemination of the textual productions of the religious-judicial elite (al-'ulamā'). Paradoxically, indeed incredibly, in an overwhelmingly illiterate society, the diffusion of these texts mediates as well as disciplines the theocratic regime's subjects into a polity through a process of "textual domination". Messick seems justifiably doubtful about the theoretical plausibility of his "discursive history" as he ends it with an ironic disclaimer that suggests an opportunistic theoretical instrumentalization of others' historical experience: He refers to the nonexistence of a "specific polity" but merely an imaginative "construct" of a "composite of historical materials" [17, p. 255].

Gabriele Vom Bruck's ethnography, Islam, Memory, and Morality in Yemen, is a narrative about a textmediated adjustment strategy deployed by a cohort of hereditary elite (al-sāda) who held government posts in the Imamate and are afflicted with a politically engendered existential condition - societal exclusion under the new republican regime in the post-1962 revolution period. Her subjects' predicaments are abstracted through Bourdieu's symbolic lexicon as they are made to participate in a "moral economy" within the private sphere through reliance on their "cultural capital" (i.e., their expert knowledge of the Zaydi creedal repertoire) as they perform taqlīd (the recitation of Zaydi religious texts). In this way an existential condition is remedied through a symbolic act. As taqlīd instantiates a "habitus" through which they engaged in the quietist propitiation of the state's animosity towards them and a discursive accommodation to their status demotion, social exclusion and political subordination. However, this quietism is at odds with the sāda's activist doctrinal imperative: namely "to ordain right and forbid wrong", which is pursued through the practice of khurūj (i.e., rising against an unjust ruler) that obliges its adherents to oppose injustice. The author's preference for examining her research subjects' domestic management of their social exclusion through "moral rearmament", instead of their historical agency within the public sphere, led her to neglect khurüj. It is the latter that helps us understand the initial motivation of the current rulers of parts of Yemen (al-Hūthi tribe) who are the progeny of the sāda $[18,19]$.

The framing conceit of these theories' Eurocentric genealogy and comparative standpoint subordinates disciplinary practice to the primacy of the Western episteme and sensibility and reifies the anthropology of the political into a survey of the effects of Western societies on non-Western ones. The end result is the generification of the world's societal and institutional diversity through the diffusion of a regional ethnoepistemology that insists on its universal relevance and thus distorts the empirical elucidation and theoretical explanation of other regions. Moreover, these theories are consensually subservient to an idealized model of liberal democracy and to an extroverted neoliberal political economy as a universal comparative framework. This comparative framework is based on an anachronistic ideal animated by a delusional conviction about the historical inevitability, and permanent sustainability, of the Western model's global hegemony. The use of both the theoretical quartet and the dysfunctional neoliberal democracy model $^{1}$ betrays

\footnotetext{
1 Indeed, existing liberal democracies in their milieu of origin can be described, at best, as "relative democracies" given their endemic deficiencies: The upper-class bias of their policies, the mass inequality produced by their economic regime, the hierarchical racial classification of their polities, the bribes-mediated election of their political representatives, and the political subordination and financial dependency of their governments on a class of plutocrats. Moreover, the chronic spectacle of political entropy, and systemic dysfunction displayed by the Euro-American exemplars of such a regime betrays a credibility deficit about its promises and suggests an intrinsic vulnerability to elite capture, and thus ultimately represents a status quo maintaining, not transforming, political regime. For the globe-trotting "liberal universalists" promoting democracy abroad through a deceptive rhetoric and venal ethic, this presents an obligation to spread the message in their home countries in the Global North that democracy cannot be exported through a Western hegemony sustaining project, but through the authentic
} 
their advocates' imperious intellectual sensibility as they authorize the historical disembedding and analytical instrumentalization of non-Western social formations. Moreover, their continued use as the prevailing knowledge production templates, or society cloning toolkit, is no longer legitimate in the emerging post-universalist conjuncture of the social sciences. This conjuncture's three defining characteristics deflate the globalizing pretention of such practices: (a) the intrinsic individuality and thus non-convergence of the historical trajectories of each one of the world's panoply of social formations; (b) the inexorable divergence of the institutional configuration of their polities; and (c) the incommensurable plurality of values that motivate their aspirational horizons [20].

This article offers a meso-analytical synopsis of the underlying and constantly evolving power dynamics of state politics in Yemen that reconstructs the Yemeni state's historical genealogy of emergence and anatomizes its structural transformation process. This synopsis, however, emphasizes the roles and impacts of regional and local actors and relatively neglects those of international actors. Western governments since the Cold War up to the present War on Terror, were instrumental in fostering and sustaining the Yemeni state's democracy deficit among other institutional pathologies. However, their self-serving development aid, institutional reforms and policy advice did not always initiate, but mostly exacerbated, governance dysfunctions (e.g., economic liberalization and democratization schemes that promoted crony capitalism and perpetuated authoritarianism) [see 21, $22,23]$. Accordingly, the narrative below inventories the state's varying polity formation strategies that were adopted in response to changes in its local and regional political environment. Also, it identifies the key constitutive factors that determined both the nature of state-society relations and the structure of the emergent political community: The political incorporation and administrative subordination of people and territory; the policy regime and its resource allocation rationale; the composition of elites and power distribution among them; the population's ideological mobilization to induce state identification and its

exemplification of democratic practices "back home", especially toward racialized minorities, ethnicized immigrants and the marginalized working classes. Sadly, an ever increasing proportion of the Global North's polities have opportunistically abandoned their specious profession of a tolerant liberalism to furiously embrace a primal xenophobia that shuns human diversity and promotes the West as a demographic exclusion zone. political socialization to engender polity formation; and the coercive interventions of regional powers and their institutional ramifications. To understand their operation and effects in Yemen, I engage in a temporally demarcated analysis of nation-state formation and state-society relations embedded within their communal, national and regional dynamics. My approach to political anthropology privileges a historical contextualization of the exigencies animating the state's governance strategies and an analytical assessment of their effects on nation-state formation and state-society relations. In doing so, it identifies the vectors that generated the conditions of possibility for establishing a Yemeni political community.

The information on which this article is based were accumulated over a dozen years of resident social learning through continuous experiential immersion in Yemeni society as a United Nations development professional and subsequently as a local researcher. Also, as a long-term resident I was a client of government services, and a participant in all of the routines of an ordinary citizen's daily life. This is complemented with a critical engagement with the relevant scholarly literature on history, politics and the policy literature of international agencies. There is, however, a caveat: While my disciplinary training was in anthropology the narrative that is offered below is not an ethnographic one, as I do not share its foundational assumption that the domain of micro-relations (i.e., accounts of the individual experiences of both researcher and research subjects) is the primary generative source of social reality, which leads to the fetishism of the minutiae of everyday life. Moreover, I reject the ethnocentric practice of anthropology, which privileges the dissemination of metropolitan travelling theory instead of theory formation grounded in the local research context. Accordingly, I adopt a mesographic approach [see 24, 25], which (a) sunders the imagined umbilical cord between anthropology and ethnography and substitutes the latter's self-centric research protocol with a socio-centric one (i.e., mesography); (b) assumes that the individual is the sentient artefact of the collectivity's shared horizon of possibilities allowed by the prevailing state-society covenant; and (c) postulates that this covenant incubates the social opportunities around which everyday life is organized. This approach entails a constellational perspective that encompasses multiple analytical scales to produce a history-embedded and institution-mediated explanatory narrative about the formation of a social collectivity into a political community. Accordingly, it situates the 
research domain within its historical context (i.e., historical genealogy), anatomizes the macro-structural processes (i.e., state formation), in order to elucidate the effects on meso societal structures (i.e., institutions formation) and on micro local life-worlds (e.g., citizens' agency). The next section analyses the historical vectors that led to the Yemeni state's adoption of an existential politics and inventories the effects on the nation-state nexus.

\section{STATE EXISTENTIAL POLITICS: FRACTURING THE NATION-STATE}

The Yemeni case illustrates the effects of pathdependence as an axiom of state formation: Catalytic socio-political events engender pivotal historical conjunctures, which determined the conditions under which states made strategic decisions; and once these decisions are taken, they tend to become an irreversible and permanently constraining political and institutional legacy. How Yemen's institutional evolution got stuck in a path-dependent trajectory is axiomatically expressed in this way by Slater [26]: "by organizing actors in particular ways at the outset of a new political dispensation, leaders create structures that assume a momentum of their own" (p. 18). This is exemplified in the seminal effects on state-society relations from the fact that the civil war ended in a relative stalemate between the two antagonists, as Burrowes [27] identified them in the then prevailing nomenclature: The majority "traditionalists" (al-taqlīdiyyun) made up of tribal groups and religious conservatives, and the minority "modernists" (al-'așriyyun) composed of educated professionals and urban residents. This resulted in the neutralization of the modernist aspirations of the revolution as the traditionalist forces achieved representational parity, if not primacy, in all state institutions. The ensuing national reconciliation promoted a minimalist conception of national unity, as it authorized the practice of regional sovereignty, which institutionalized the regional and military autonomy of the northern tribal formations into a plethora of sovereign enclaves under primordial leadership. This led to the consolidation of the political dominance of politically opportunistic shaykhs willing to generate rent from their tribes' warrior ethos over a rural-led economy and over a national population that was overwhelmingly rural $(93 \%$ in 1970) and already organized into fragmented tribal formations. Moreover, the mountainous topography of the national territory with a widely dispersed residential pattern of low population density presented a perennial challenge to the Yemeni state capacity to project its authority beyond urban areas, and thus ensured the tribal shaykhs' role as politically indispensable state partners.

The discussion that follows addresses the critical factors that circumscribed the trajectory of nation-state formation in Yemen: (i) it identifies the key policy decisions about institutional choices and political actors that consolidated into vectors of state formation; (ii) it presents a historical overview of the Yemeni state's evolution; (iii) it analyzes the rise and demise of nationalism as an ideology of polity formation and social cohesion; (iv) it elucidates the effects of regional influences on state structure and political culture; $(v)$ it explains the persistence of primordial structures in the national polity's configuration; (vi) it describes the nature of the regime and its maintenance strategies; and (vii) it illuminates the state's governance culture through a comprehensive tabular presentation of its operational norms.

\subsection{Path-Dependence Vectors: Institutionalizing History}

The structuring vectors of Yemen's contemporary architecture of state-society, or nation-state, relations were inaugurated within the immediate aftermath of the 1962 revolution. Indeed, within a month after the revolution, the government promulgated a number of decrees that sought to institutionalize the role of tribes within the state. The establishment of the Supreme Defense Council gave a prominent role to the "warranty shaykhs" (al-mashāyikh al-ḍamān) the senior tribal leaders of the north. The following year, more tribespromoting institutions were established: The Supreme Council for Tribal Affairs was created and placed under the chairmanship of the President of the Yemen Arab Republic (YAR); tribes were required to establish Tribal Shaykhs' Councils throughout the new Republic at the governorate and at the district and sub-district levels. In addition, there were the Central Committee for Tribal Affairs, and the Ministry of Tribal Affairs. The latter was replaced in 1968 by the Department of Tribal Affairs, which is still the main liaison agency between the state and the tribes and its primary responsibility is the distribution of monthly stipends to tribal shaykhs [28]. Furthermore, the 1970 constitutional ban on the formation of political parties (Article 37: "Partisanship in all its form is prohibited") prevented the organized political mobilization of urban-based groups that could counter the political hegemony of tribes. As a result, the first parliamentary elections held in 1971 led to the establishment of the Consultative Council (majlis alshūrā) as the first national legislative institution whose 
159 members were overwhelmingly tribal shaykhs. This tribe-centric institutional structure (a) engendered a transition from an autonomous tribalism under the Imamate to a state-incorporated tribalism under the new republic; (b) consecrated the tribes as the preeminent national power broker in the emergent civilpolitical society of the YAR; and (c) consolidated the traditional social structure to the detriment of the emergence of a modern one. Subsequently, the dominant political orientation and institutional configuration of the YAR was dominated by a triumvirate of political actors: The military, the tribes and the Islamists. These actors were to determine the nature of the unification of the two Yemeni states through an "annexationist politics" and maintained their influence over the politics of the unified Yemeni state to the present [29].

This was the condition of possibility that constrained the state into a patronage system in which, initially, state policy privileged primordial affiliations based on tribes and regions, and emphasized the cooptation of their most influential individual representatives, to whom was bestowed the prerogative of controlling and mobilizing their particular constituencies on behalf of the state. Indeed, tribes were perceived as selforganizing communities, and were promoted as the foundational political unit of the state. This led to the permanent institutionalization of the "stipendiary regime": The quintessential practice (which was employed prior to the dawn of Islam, during the Imamate period and ever since the 1962 revolution) of paying tribes a regular stipend, or more accurately a bribe, in exchange for not challenging the state's authority and for their service as mercenary forces. The state relied on this practice as its primary means of placating its potential political challengers and of maintaining its political stability. In this way, the state systematically nurtured, while it tactically contained, the centrifugal forces represented by the regional tribal formations. This strategy subsequently became an indispensable part of the Yemeni state's modus operandi. During, and since, the civil war the Yemeni state engaged in a competitive bidding contest with Saudi Arabia for the loyalty of these arms-bearing tribes, who can be mobilized into militias against or for the state. $^{2}$ The political exigency to accommodate

\footnotetext{
${ }^{2}$ Indeed, from the 1970 s onward tribal stipends were one of the principal sources of the state's chronic budget deficit. For example, in 1971 nearly 40 million riyals were allocated to tribes, while the government collected taxes
}

these centrifugal forces partly prevented the Yemeni state from achieving the basic axiom of state formation: Monopoly over the legitimate means of violence that would have enabled the state to establish unitary sovereignty over the national territory. However, tribalism in contemporary Yemen is not a natural social, cultural and political heritage, partly bequeathed by its ecological milieu - i.e., the geographically remote and topographically mountainous and thus isolated nature of their residential habitats. Instead, tribalism's modern manifestation derives from a history-contingent, powerdriven, culturally-adapted, and politically-molded social organization managed by opportunistic and politically entrepreneurial local/regional shaykhs who were selectively supported by regional powers to establish and sustain their hegemony over their rural fiefdoms as primordial polities. ${ }^{3}$

The state's failure to achieve both monopoly over arms and sovereignty over territory was to exercise a permanent centrifugal effect on nation-state formation and state-society relations. The end result was a chronic condition of "aborted state and nation-building", that eventually led to the consecration of tribes as the primary, if not sole, means available to the Yemeni state initially to establish, and subsequently to sustain, the local administration of an overwhelmingly rural polity [33]. The 1962 revolution dethroned the traditional ruling class (al-sāda) and marginalized their administrative classes of clerics (al-'ulamā') and judges (al-quda). They were not replaced by a modern national bourgeoisie in the state's leadership ${ }^{4}$, but by an opportunistic aggregation of corporate groups

(zakāt) were less than 11 million riyals [30, p. 262]. When the Prime Minister at the time decided to eliminate this stipendiary regime he was forced to resign [31]. This regime has ever since constrained state governance.

\footnotetext{
3 This argument is contrary to the recurrent use of the discredited Orientalist thesis that tribalism is an ontological fatality of peoples and the historical destiny of countries in the Middle East/West Asia region, which is considered a bastion of irremediably primordial states: "tribes with flags" (see

${ }^{4}$ Yemen's socio-political environment did not enable the emergence of a modern nationalist bourgeoisie as the state's political leadership. However, there was a relatively small cadre educated abroad who constituted a secular minded and reformist middle class that was recruited into the state bureaucracy as its technocratic servants [34]. One shaykh from a prominen qāọi family described this class of technocrats as 'abd al-mukhlaș lil dawlah ("faithful slave of the state"). Indeed, their subservient role is exemplified in the memoirs of Muhsin Al-'Ayni (see [31]). Whatever class passes for a bourgeoisie in Yemen is conscripted into the state as its venal retainers.
} [32]). 
dominated by military strongmen as heads of state in collusion with tribal shaykhs as war lords. This new "elite" was primarily endowed with coercive capital, which incentivized factional competition over territorial sovereignty, and thus sustained the regional fragmentation of the country and polity. Consequently, they failed to pursue national polity integration and the structural transformation of society.

The genesis, reproduction and change of this political legacy is summarized in Table 1, which offers an overview of the changing nature of the state in Yemen over a century demarcated into different historical conjunctures. The tabular presentation (a) provides a genealogy of Yemen's modern nation-state formation process that belies the assumption of historical immutability; (b) outlines the structural anatomy and identifies the vectors of change for each of the different regimes; and (c) proposes a new political taxonomy for the Yemeni state that replaces the prevailing descriptive terms that are of little heuristic value (e.g., "pluralized authoritarianism", "unique authoritarianism", "competitive authoritarianism", etc.). The title of each regime is based on the dominant characteristic of its power configuration: Tribal libertarianism is based on a network of bilateral agreements between the state as a monopolistic agency and selected tribal shaykhs as client groups to ensure their political allegiance. Primordial federalism is based on the shared sovereignty between an urban-based military-led regime and rural-based leaders of tribal confederations with delegated jurisdictional authority. Republican tribalism entailed the incorporation of the south into a unified national polity based on the tribal administrative practices of northern civic tradition that promotes a polity organized into tribes. And cabalistic corporatism reflects the transition from an extended familycircumscribed authoritarian rule to an oligarchic coalition based on a regime maintenance pact between selected representatives of corporate groups. Accordingly, the table identifies the catalytic events that initiated the formation of each type of regimes, and highlights their impacts on polity configuration, the culture of governance and the economic underpinnings [35]. Two caveats: First, the table merely serves as historical background to the analysis of the nature of the contemporary regime; and second, it does not include the transitions of the south Yemeni state (19671990), given the ultimate primacy of the northern regime following unification.

Table 1: Transitional Phases of State Formation in Yemen

\begin{tabular}{|c|c|c|c|c|}
\hline \multirow{3}{*}{$\begin{array}{l}\text { Defining } \\
\text { Aspects }\end{array}$} & \multicolumn{4}{|c|}{ Regime Types } \\
\hline & Tribal Libertarianism & Primordial Federalism & Republican Tribalism & Cabalistic Corporatism \\
\hline & Pre-revolution (1918-1962) & Post-revolution (1962-1990) & Unification (1990-2000) & Implosion (2001-2012) \\
\hline $\begin{array}{c}\text { Catalytic } \\
\text { Events }\end{array}$ & $\begin{array}{l}\text {-1918 inaugurates } \\
\text { independent Imamate after } \\
\text { withdrawal of Ottoman } \\
\text { Turks. } \\
\text {-1920s and beyond state } \\
\text { operates as an extensive tax } \\
\text { extraction apparatus over a } \\
\text { polity of subjects whose } \\
\text { raison d'être is to pay tax. } \\
\text {-1930s heralded mass } \\
\text { emigration of Shāfi' } \\
\text { merchants and peasants in } \\
\text { protest of excessive } \\
\text { taxation, which led to } \\
\text { organized political } \\
\text { opposition. } \\
\text {-1934 Saudi Arabia's } \\
\text { capture of Yemen's territory } \\
\text { led to social reform } \\
\text { movements and the rise of } \\
\text { the Free Yemeni Movement } \\
\text { and ultimately to the 1962 } \\
\text { revolution. }\end{array}$ & $\begin{array}{l}\text {-1962 Revolution was } \\
\text { trapped into an "Arab Cold } \\
\text { War" between Egypt and } \\
\text { Saudi Arabia. } \\
\text {-1962-1970 civil war } \\
\text { instituted a power asymmetry } \\
\text { between rural communities } \\
\text { and urban society. } \\
\text {-1970s policy decisions led } \\
\text { to permanent dependence } \\
\text { on tribes as pillars of the new } \\
\text { state. } \\
\text {-1974-1977 under al- } \\
\text { Hamdī's rule sought in vain } \\
\text { to break tribal domination of } \\
\text { the state and society. } \\
\text { - } 1978 \text { rise of 'Alī 'Abdāllah } \\
\text { Șālih as YAR's President } \\
\text { consolidated use of tribes in } \\
\text { territorial governance. }\end{array}$ & $\begin{array}{l}-1990 \text { (May 22) unification } \\
\text { of North and South Yemen } \\
\text { into the Republic of Yemen. } \\
\text {-1990 (August 2) Iraq's } \\
\text { invasion of Kuwait and } \\
\text { Yemen's neutrality towards } \\
\text { it led Gulf monarchies to } \\
\text { expel one million migrants } \\
\text { ending the flow of } \\
\text { remittances. } \\
\text {-1993 parliament elections } \\
\text { dashed the unification } \\
\text { vision of the South. } \\
\text {-1994 civil war led to the } \\
\text { hegemony of North's tribe- } \\
\text { centric regime. } \\
\text {-1999 first Presidential } \\
\text { elections won by Saallih } \\
\text { entrenched the family ruled } \\
\text { shadow state. }\end{array}$ & 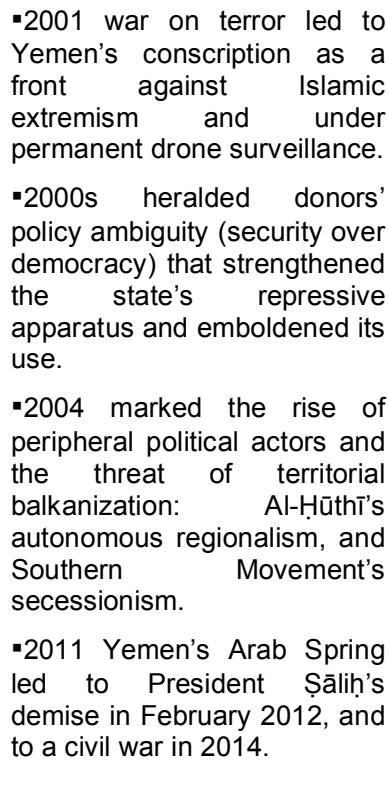 \\
\hline
\end{tabular}




\begin{tabular}{|c|c|c|c|c|}
\hline $\begin{array}{l}\text { Actor } \\
\text { Netwo }\end{array}$ & $\begin{array}{l}\text { - Hegemony of a hereditary } \\
\text { ruling dynasty governing a } \\
\text { polity of subjects organized } \\
\text { into a hierarchy based on } \\
\text { religious, genealogical and } \\
\text { regional criteria. } \\
\text {-Collusion of a status-based } \\
\text { elite with selected tribes } \\
\text { against the peasantry and } \\
\text { small merchants. } \\
\text {-Recognition of tribal } \\
\text { jurisdictional sovereignty as } \\
\text { the Imam selectively sub- } \\
\text { contracted northern tribal } \\
\text { shaykhs as retainers of the } \\
\text { state, and their tribes as } \\
\text { state militias. }\end{array}$ & $\begin{array}{l}\text { - Concentration of power in } \\
\text { heads of armed forces, } \\
\text { important tribal shaykhs, and } \\
\text { Sunni Islamists. } \\
\text {-Rise of Local Development } \\
\text { Associations (LDAs) in } 1963 \\
\text { for the economic } \\
\text { development of rural life. } \\
\text {-Start of Saudi Arabia's } \\
\text { hegemonic influence in } \\
\text { Yemen's politics through } \\
\text { bribing of key tribal actors. } \\
\text {-Consolidation of a socio- } \\
\text { political power imbalance } \\
\text { between a weak central state } \\
\text { and strong rural non-state } \\
\text { actors. }\end{array}$ & $\begin{array}{l}\text {-Military-led regime with } \\
\text { officers in civilian suits } \\
\text { incarnated power } \\
\text { permanently. } \\
\text { - Institutionalization of most } \\
\text { tribal shaykhs as retainers } \\
\text { of the state, and of political } \\
\text { nepotism in key state and } \\
\text { society's institutions. } \\
\text {-Southern polity's political } \\
\text { agency is disabled by state } \\
\text { policies that produced } \\
\text { unequal citizenship. } \\
\text {-CSOs multiplied in } \\
\text { response to donors' } \\
\text { initiatives for democracy } \\
\text { promotion and } \\
\text { development. }\end{array}$ & $\begin{array}{l}\text {-Full normalization of the } \\
\text { practice of elite patronage and } \\
\text { mass clientelism assimilated } \\
\text { the national polity into the } \\
\text { venal culture of state } \\
\text { governance. } \\
\text {-Disciplinary effects of this } \\
\text { governance culture led to: (a) } \\
\text { the public sector's endemic } \\
\text { ethical deficit; (b) the private } \\
\text { sector's mutation into a rent } \\
\text { seeking network; (c) civil } \\
\text { society's adoption of an ethos } \\
\text { of financial opportunism; (d) } \\
\text { citizens' addiction to financial } \\
\text { incentives; and (e) political } \\
\text { opposition's submission to an } \\
\text { ethic of accommodation. }\end{array}$ \\
\hline $\begin{array}{c}\text { Governance } \\
\text { Logic }\end{array}$ & $\begin{array}{l}\text {-Feudal governance } \\
\text { practices: e.g., hostage- } \\
\text { taking of sons of main tribal } \\
\text { groups as rebellion } \\
\text { prevention measure; and } \\
\text { selective insulation from the } \\
\text { outside world. } \\
\text {-Strict policing of a sectarian } \\
\text { division based on status- } \\
\text { prescribed social roles } \\
\text { between Zaydī tribesmen } \\
\text { and Shāfi'i townsmen. } \\
\text {-Sharīa was the theocratic } \\
\text { state's legal framework } \\
\text { adjudicated by a religious } \\
\text { elite, al-'ulamā'. } \\
\text {-Territorial control is } \\
\text { exercised through the } \\
\text { tactical incorporation of most } \\
\text { important tribal federations. }\end{array}$ & $\begin{array}{l}\text {-State's de facto recognition } \\
\text { of tribes as autonomous } \\
\text { communities in a } \\
\text { geographically dispersed and } \\
\text { regionally segmented polity. } \\
\text {-Shared } \\
\text { between state and primordial } \\
\text { groups in which urban areas } \\
\text { are under state jurisdiction } \\
\text { and rural areas are under } \\
\text { tribal sovereignty. } \\
\text {-State legitimacy depended } \\
\text { on accountability to tribes' } \\
\text { interest and their inclusion in } \\
\text { state institutions. } \\
\text {-Selection of state leadership } \\
\text { through military and tribes } \\
\text { brokered appointment, not } \\
\text { through election. }\end{array}$ & $\begin{array}{l}\text {-Inauguration of multi-party } \\
\text { electoral politics unleashed } \\
\text { the state's generalization of } \\
\text { clientelist politics as } \\
\text { national polity's political } \\
\text { incorporation strategy. } \\
\text {-Administrative } \\
\text { incorporation of the South } \\
\text { through the North's } \\
\text { organizational vernacular } \\
\text { atrophied institutional } \\
\text { modernization and } \\
\text { corrupted state's republican } \\
\text { form. } \\
\text {-Political hegemony of } \\
\text { traditional northern } \\
\text { sociocultural practices led } \\
\text { to re-tribalization of the } \\
\text { southern polity and its } \\
\text { enforced pietization by the } \\
\text { state's Islamist proxies. }\end{array}$ & $\begin{array}{l}\text {-Establishment of elected } \\
\text { Local Councils in } 2001 \text { led to } \\
\text { total subordination of regional } \\
\text { and local councils to the } \\
\text { central government. } \\
\text {-State's tactical alternation } \\
\text { between political liberalization } \\
\text { and de-liberalization as a } \\
\text { deceptive means of complying } \\
\text { with donors' requirements. } \\
\text {-Recruitment of CSOs as } \\
\text { retainers of state, proxies of } \\
\text { political factions, and courtiers } \\
\text { of foreign donors' interests. } \\
\text {-State's vertical accountability } \\
\text { to corporatist elites prevails } \\
\text { over its horizontal } \\
\text { accountability to ordinary } \\
\text { citizens. }\end{array}$ \\
\hline $\begin{array}{r}\text { Ecor } \\
B\end{array}$ & $\begin{array}{l}\text {-Collapse of the coffee trade } \\
\text { and end of Ottoman } \\
\text { patronage led to the state's } \\
\text { total dependency on the } \\
\text { direct taxation of the } \\
\text { population, and to the shift } \\
\text { from subsistence to } \\
\text { commercial qāt cultivation to } \\
\text { replace coffee as cash crop. } \\
\text {-Every hamlet, village and } \\
\text { town was a fiscal extraction } \\
\text { unit in which Shāfi'i } \\
\text { merchants and peasants } \\
\text { were taxed } \\
\text { disproportionately. } \\
\text {-Strategic distribution of tax } \\
\text { farming privileges as } \\
\text { patronage to selected tribes } \\
\text { and status groups. }\end{array}$ & $\begin{array}{l}\text {-Labor remittances from } \\
\text { Yemeni migrants in the } \\
\text { Arabian Peninsula funded } \\
\text { LDAs projects, which } \\
\text { exceeded government } \\
\text { contribution to GNP, and } \\
\text { their imports were the main } \\
\text { source of government } \\
\text { revenues through customs. } \\
\text {-Discovery of oil in Mā'rib in } \\
\text { 1984 generated carbon rent } \\
\text { that initiated the state's fiscal } \\
\text { independence from the } \\
\text { population. } \\
\text {-Rise of qāt production as a } \\
\text { pillar of the rural economy } \\
\text { and the constitution of a qāt } \\
\text { lords lobby. }\end{array}$ & $\begin{array}{l}\text {-Discovery of oil in } \\
\text { Hadramawt in } 1992 \text { led to } \\
\text { consolidation of carbon rent } \\
\text { dominated economy and to } \\
\text { the state's complete fiscal } \\
\text { autonomy from the polity. } \\
\text {-Structural adjustment } \\
\text { program in } 1995 \text { mobilized } \\
\text { Western aid, and placed } \\
\text { national economic policy } \\
\text { under the managerial and } \\
\text { political diktats of Western } \\
\text { donors. liberalization } \\
\text {-Economic to crony } \\
\text { measures led to a } \\
\text { capitalism based on a } \\
\text { corrupt economic } \\
\text { sovereignty protection } \\
\text { strategy for an elite cabal. }\end{array}$ & $\begin{array}{l}\text { - International community } \\
\text { entered into an implicit } \\
\text { resource allocation pact to } \\
\text { sustain regime's stability to } \\
\text { fight war on terror. } \\
\text {-Start of natural gas export in } \\
\text { October } 2009 \text { replenished the } \\
\text { regime resources to co-opt } \\
\text { political challengers and } \\
\text { enrich capitalist cronies. } \\
\text {-International aid was } \\
\text { allocated (a) to training and } \\
\text { arming security forces, (b) to } \\
\text { a cynical philanthropy that } \\
\text { promotes a dependent } \\
\text { "development", and (c) to } \\
\text { ineffectual radicalization } \\
\text { prevention experiments. }\end{array}$ \\
\hline
\end{tabular}

\subsection{Nationalism: Contingent Process \& Expedient Discourse}

Nationalism expresses the constitutive symbiosis between nation and state. As Smith [36] noted: "The state [is] the necessary condition and matrix for the gestation of national loyalties" (p. 59). Hence the importance of clarifying the emergence, mutation and ultimate demise of nationalism in Yemen. This is all the 
more necessary in view of the recent publication of three texts that focused on the intersection of nation, state and nationalism in Yemen and that examine whether the rise of a unified Yemen is the product of a historically inherent or contingent process. Unwittingly, all three texts rehearse the perennial contention paraphrasing Anderson [11] - between nationalists' insistence on the "subjective antiquity" of their nation, and historians' contrary assertion of its "objective modernity" (p. 5).

Willis' book [37] offers a counter-narrative of Yemen's nation-state formation process between 1857 and 1934 that is "meant to evoke possible histories rather than a single and hegemonic history" (p. 14). Its primary aim is "to question the inevitability and naturalness of a unified Yemen by engaging in the type of history of spaces and powers... [that] destabilizes the historicism of modernity and its agents" (p. 6, 8). This is pursued though a Foucault-inspired interpretive reconstruction of historical archives. The resulting narrative privileges an externally mediated "spatial history of modern Yemen", while it rejects the locally produced "national historical narrative of modern, unified Yemen [that] has assumed the presence of a singular Yemeni space and identity waiting to be discovered" (p. 198). Accordingly, he "spatially" articulates North Yemen's state formation with a panIslamic polity constituted by an "anti-imperialist SunniSalafi movement", in which the Imam was supposed to be a leading protagonist. And South Yemen is theorized as being "inextricably entwined" to the "durbar form of rule" of British India's "Ornamentalist" project of state-building as spectacle, which caricatures the South into "Aden and the nine tribes" as an instantiation of the Raj and its constellation of native Indian princes (see [38]). The book betrays a postmodernist theory-led interpretivism that exoticizes research subjects' historical experience and that turns history into a "what if" epistemological experiment.

Day's project [39] is to discard once and for all Yemen's "unionist mythology", which served as its ideology of nationalism, with its "illusory notion that one people, the sons of Qahțān, ever lived in unison on a single territory... from ancient to modern times" (p. 43). In fact, the "sons of Qahțān" is the legacy of an early medieval discursive formation known as the "Qahțān Saga" that articulated a culture war (still continuing) that was initially founded on the comparatively rich civilizational endowments of southern Arabs over their civilization-deprived northern counterparts. ${ }^{5}$ After the 1962 revolution, it served not as a nationalist ideology but as an ostracizing political slogan for the ethnocultural delegitimization of the former ruling class of the Zaydi Imamate (al-Sāda) who were of northern Arab origin as the descendants of 'Adnān and thus considered inauthentic Yemenis. Betraying a misunderstanding of Yemeni politics, the author imperiously asserts that Yemen was never destined to be either a unitary state or a unified nation, as it was always riven by endemic regionalism, which is the source of all of its contemporary political problems (see [41]). As a solution, he arbitrarily divides the country into seven ethno-regions based on a set of whimsical criteria that includes culinary and sartorial markers. Unhelpfully, the concluding sentence of the book essentializes Yemen's geography and polity with a prophecy: "Yemen will endure as a fragmented polity, just as it has for millennia" (p. 311).

Wedeen studies the manifestation of Yemeni nationalism through a "performative politics of words", in which public discourse substitutes for state institutions [42]. Intriguingly, she contests the modernity of nationalism based on the mistaken "historical connection in the West between the idea of the nation and the project of secularism". In contrast, she argues that "nationalism often develops in tandem with other ideologies or master narratives, and sometimes combines with them" (p. 14). This argument merely confirms the discursive instrumentality, and thus demagogic invocation, of nationalism, as Wimmer and Feinstein explains [5], since "dynastic rulers sought to contain nationalism by adopting it as a state doctrine themselves" (p. 768). This is exemplified in the case of North Yemen's theocratic regime, which opportunistically joined the United Arab Republic (see below). By insisting that the presumed symbiosis between nationalism and secularism is a liberal teleology and making it her cheval de bataille, she betrays a liberal epistemic charity toward the arrogated legitimacy and parodic modernity of anachronistic theocratic and primordial regimes. This obviates the historical significance of changes in the institutional infrastructure of the state and in the configuration of its

\footnotetext{
${ }^{5}$ According to Mahoney [40], the Yemeni polymath Abū Muhammad alHasan al-Hamdānī (893-945) was "the most celebrated advocate of the Qahțān Saga in the early medieval period." And his 10 volumes Al-Ik/il (The Crown) "represents a celebratory works that establishes the identity and superiority of the South Arabian tribes", (p.69)
} 
polity as occurred in North Yemen's transition from a pre-modern polity hierarchically segregated into status groups and sects under the coercive rule of a theocratic state, to a modern political community with representative institutions for a national polity of sovereign and equal citizens envisioned by the 1962 revolution.

Alas, these scholars' discussion of the nature of nationalism and nation-state formation in Yemen is burdened by instrumentalizing discursive practices: The idiosyncratic historicization of the country, the interpretive decontextualization of local facts, and the theoretical dis-embedding of research subjects from their local structures of experience. The end result are narratives of even less plausibility than the Yemeni "myth", which leave the reader bereft of a grounded understanding of the mechanism of nationalism's emergence and subsequent mutation in Yemen. These authors' arguments are rendered moot by the fact that historical contingency was always the driving force both in the divergent trajectories of the rise of the modern state and its founding ideology of nationalism. Indeed, contingency is the norm in all the key texts on nationalism regardless of the perennialist or inevitabilist claims of elite protagonists [11, 43, 44]. The critical issue is to identify the actual trajectory of its adoption within a given social formation. In the case of Yemen, the emergence of the modern nation-state and nationalism is contingently situated within the synergistic conjuncture between the following factors: (a) the demonstration effects of a regional model; (b) the intensification of political conflicts between segments of society; (c) the availability of technology of dissemination and of coercion; and (d) elite-induced public demands for social transformation that would establish a polity of equal citizens within a modern nation-state. ${ }^{6}$ Indeed, Fred Halliday's 1997 article [45] deploys a "comparative contingency" approach to illustrate how both North and South Yemen accommodated those factors in their distinctive ways. As he explained: "what might seem to be exogenous, mimetic, adoption of general Arab nationalist terms concealed a modular, endogenous usage" among northern and southern political leaders. And Abdallah

\footnotetext{
${ }^{6}$ Cf. Hobsbawm [44, p. 10] and Wimmer and Feinstein [5, p.769-770]. Noteworthy is that these four catalytic factors in the constitution of Yemen's national "imagined community" are different from, and thus suggest the limited applicability of, Anderson's [11] global hypothesis about nation formation: "a system of production and productive relations (capitalism), a technology of communications (print), and the fatality of human linguistic diversity" (p. 43).
}

Bujra [46] depicted how these factors played out in the rural areas of the South through the capillary effects of an anti-colonial national liberation movement on the introduction of modern form of collective loyalty (citizenship) over primordial ones (tribalism), and on the replacement of hierarchical social relations with egalitarian ones. The historical trajectory of the rise, adoption and demise of nationalism in Yemen generated by the contingent interaction of the above factors can be schematized in a three phase process:

- The first phase was inaugurated with the "contagion effect" of the supra-nationalism discourse of pan-Arab nationalism (al-qawmiyya al-arabiyya) emanating from the regional exemplar of Egypt from 1952, which was amplified by the pan-regional reach of its radio station Sawt al-'Arab (Voice of the Arabs) that attacked the monarchies of the region and promoted revolutionary republican forces. The ultimate aim of this ideology was to achieve Arab political unity within a singular sovereign republican state spanning the entire region. This revolutionary republican experiment was inaugurated with the founding in 1958 of the United Arab Republic (UAR) through the union of Egypt, Syria and incongruously Yemen's Imamate. $^{7}$

- $\quad$ The second phase began after the failure of the UAR experiment in 1961, which led 'Abd al-Nāșir in 1963 to abandon the political goal of Arab territorial unity in one state in favor of Arab doctrinal unanimity among individual states [47, p. 1]. This engendered the local adaptation of the pan-regional ideology into the practice of a meso-nationalism to be enshrined in an independent state guided by a modern, secular and developmental creed. In Yemen this mesonationalism was introduced in the North by the 1962 revolution that was driven by an "antiabsolutist" discourse against a sectarian and feudal theocracy. And subsequently it was inaugurated in the South by the 1967 revolution

7 In March 1958, Imam Ahmad volunteered his ultra conservative Mutawakkillite Kingdom of North Yemen as a junior partner of the UAR, which was, as Ferris [4] puts it "the grandest pan-Arab experiment of the century". Out of mutual political convenience the Egyptian President accepted the Imam's offer and the UAR was renamed the United Arab States (UAS) and lasted until December 1961. The Imam's primary motivation was to use the UAS as a security buffer against Saudi Arabia (see p. 33-34). 
animated by a national liberation discourse against a Western colonial power. Unification in 1990 failed to institutionalize a functioning modern state with an integrated national polity of equal citizens. The unified state chronic performance failures transformed the national polity into regional enclaves of political disaffection against it, which created a context for the re-emergence of centrifugal forces.

- $\quad$ The third phase was triggered by the 1994 civil war, which was won by the northern regime. Its defining feature was the unified state's failure to nurture a "horizontal comradeship" between it and the nation's citizens, preferring instead to promote a "vertical clientship" with the representatives of selected groups. This subverted the development of affiliative sentiments among the national polity vis-à-vis the state, and instead generated the rise of subnational allegiances in the form of an infranationalism: This entails the fracturing of the national polity into regional and/or communal social formations through a process of a reactive localization of political loyalties, as these subnational formations asserted their autonomy from the illegitimate central state. This engendered a default vernacular federalism characterized by the collective sharing of a unified national territory, while political identification is circumscribed to the regional and communal levels.

Since unification nationalism in Yemen, which was opportunistically invoked as an occasional mobilizing slogan, partly in response to the permanent culture war with Saudi Arabia, lapsed into an "intermittent mood". Indeed, nationalism did not offer an alternative narrative that was credible and nationally unifying and thus never supplanted the prevailing primordial rationales (e.g., tribalism, regionalism and confessionalism). Consequently, it failed as an ideological covenant to forge symbiotic relations between the individual, the community, the nation and the state; and thus did not serve as the reproductive means of the Yemeni nation-state. Furthermore, the perpetual interference of Saudi Arabia, which is, as Halliday [45] puts it, "the main national enemy of Yemen" (p. 35), forced the state to constantly counter its perverse influence, which distorted the articulation, if not forced the abandonment, of Yemeni nationalism from a future-oriented project of state-modernizing and nation-building, to a regressive project limited to tribesreliant regime protection and state-survival. Ultimately, this led to a national polity constituted by divergent identities, conflicting loyalties and competing sovereignties.

\subsection{Regional Contagion: Corporatist Imperative}

Modern state formation in Yemen was inaugurated through the gauntlet of its neighbors' regional power politics, and evolved under their constant threats to its sovereignty as they sought either to reduce the Yemeni state to vassal status or to sabotage the novel experiment to become the only republic in the Arabian Peninsula. As one Saudi scholar [3] confessed in a rare moment of candor in a thoroughly partisan book: "by overthrowing the monarchy and setting up a republic, [Yemen] was an indirect negative influence which could affect Saudi stability because of the possible spillover effect caused by its example" (p. 50). In spite of external attempts to derail its republican experiment, Yemen was still "muddling through", until recently, as the only multi-party democracy in the Arabian Peninsula, if merely nominally. State politics in Yemen was driven by a sense of urgency about a perennial existential threat as state leaders were compelled to shift policies between strategic resistance and tactical accommodation toward their wealthier and militarily more powerful neighbors.

The modern and democratic state that was promised by the 1962 revolution and subsequently by the 1990 unification was achieved only in form but never became one in substance. State formation in Yemen was contingent on the political machinations of its neighboring states, in particular its two regional patrons, namely the Saudi Arabian monarchy and the Egyptian republic. Given the influence of these two regional hegemons, the regional context provides a more accurate comparative frame for the Yemeni state than through its comparative deficits vis-à-vis a fictional liberal regime favored by the Western hegemony sustaining foreign democracy promotion industry. Indeed, these regional regimes' systemic features were reproduced in Yemen's political system: The chronic patrimonialism within the inner circle of power; the endemic use of financial cooptation as the sole means of eliciting political allegiance; the military autocrat in civilian suit as President; the intrinsic tendency toward hereditary succession to power; and the national economy's appropriation as the private fiefdom of the socio-political elite. Also, there is the feudalization of the state's relational norms vis-à-vis the polity (e.g., the pervasiveness of patron-client relations), which is correlated to the enduring dysfunctions (as in Egypt), or ornamental presence (as in Saudi Arabia), of 
representative institutions. One of the permanent politico-institutional consequences of this external political meddling and institutional grafting on the nature of the Yemeni state was the adoption of a corporatist mode of exercising power by the state. As Lapidus [48] explains, it is a political regime "where power is not an expression of the total society but the prerogative of certain individuals or groups [who govern] through networks of clients and retainers" (p. 364).

Indeed, Amin and El Kenz [49] suggests that corporatist governance is a pan-regional historical legacy from what they call, the tradition of "mameluke power", which entails "a complex system that associated the personalized power of warlords, businessmen and men of religion" (p. 3). This type of power shares three features: (1) the supreme authority of military institutions; (2) the interpenetration of the business world and the world of power that effaces the existence of a genuine private sector; and (3) the reliance on traditional conservative religious legitimacy (p. 9-10). Accordingly, Saudi Arabia and Egypt are both corporatist regimes that administered their polities through paternalist ministrations and dispossessed them of political agency. Saudi Arabia is ruled through a "monarchic corporatism" institutionalized in a state as the private dominion of the hereditary rule of a tribal dynasty and its retinue of genealogically linked family lineages, which is underpinned by a carbon rent producing economy that finances the cooptation of a politically neutered polity. Legitimacy is invested in the authenticity of rulers' genealogical pedigree, and sovereignty is the exclusive privilege of the ruling family and its retinue of princes. All of which are veneered by the imprimatur of Islam. In contrast, Egypt is under the rule of an "oligarchic corporatism" controlled by a military bureaucracy in collusion with a motley comprador bourgeoisie that monopolize the economy while the population is pacified through government subsidies. Legitimacy is conferred through ritualistic elections of military strongmen who assume the paternalistic mantle of father of the nation and arrogate sovereignty on behalf of an intimidated population of adolescent citizens.

In Yemen, the state evolved into a "cabalistic corporatism" based on a consociation of venal retainers selected from key social categories (e.g., tribal, business, merchants, regional, military, confessional and notable families, etc.) on the basis of their high political threat potential among other assets. Collectively, they constituted a macro-parasitical class, who appropriated the state's institutional apparatus as a convenient bargaining venue to negotiate the allocation of the nation's resources among themselves under the tutelage of the head of state. ${ }^{8}$ This initially rural-dominated consociation emerged with the inauguration of the 'Alī 'Abdāllah Șālih regime in 1978, whose political mobilization strategy was to allocate privileged access to state resources to the leadership of selected groups. Its institutional entrenchment began in the 1980s when carbon rent became available, and was fully operational in the late 1990s when the country's economy was transformed into their predatory domain. Consequently, the state was permanently organized around informal power networks operating in para-institutional enclaves wherein the politics of cooptation through government largesse prevailed. These informal enclaves systematically overruled the formal institutional channels of the public bureaucracy that mediated statesociety relations, which operationalized the national political culture into a perverse combination of patronage and clientelism.

This led to the consolidation of a corporatist sociopolitical order in which there was no competent nationalist bourgeoisie endowed with the ideological resources to establish their class hegemony over the national polity and invest the state's authority with popular legitimacy. Instead, there was a corporatist elite of a mostly rural pedigree insulated within primordial sensibilities and parochial allegiances exercising a consociational domination over the national polity. In effect, this corporatist elite is the state's privileged, if not exclusive, constituency, at it occupies an intermediary stratum between the state and the national polity and performs most of the mediating functions: Representation, mobilization, repression and extraction. Such a context was unpropitious to the politics of nationalism and its prerequisites of national polity formation and integration on the basis of social and institutional modernization. Instead, what prevailed in the aftermath of the 1970s was the construction of a post-revolution national identity based on a state-sponsored politics of cultural authenticity that was partly a reaction to Saudi Arabia's unrelenting subversive practices: Political interference, cultural condescension, economic baiting of segments of the polity and financial cooptation of the Yemeni

\footnotetext{
${ }^{8}$ According to Hill et al. [50], "Around 10 key families and business groups with close ties to the president control more than 80 per cent of imports, manufacturing, processing, banking, telecommunications and the transport of goods" (p. x).
} 
state. However, this politics adopted an impoverished version of the Qahțān Saga's discursive tradition through the state's instrumentalization of a set of traditional cultural practices (e.g., qāt chewing and tribal-related sartorial and recreational customs) as the foundation of social cohesion, national identity and state legitimacy [35].

\subsection{Segmented Nation: Dividing the Polity}

This corporatist socio-political order entailed the political disenfranchisement of significant segments of the non-tribal population, especially urban youth, women and others lacking political threat capital. This relegated a substantial proportion of the population into regional enclaves and communal fiefs under the political influence of non-state actors; hence the persistent segregation of the national polity into divergent sociocultural geographies based on a social organizational ethos differentiated along a rural-urban divide.

This peculiar rural-urban divide resulted from the fact that the Yemeni state never achieved unitary sovereignty over the national polity and territory, but instituted instead a shared sovereignty with regional tribal shaykhs over their rural domains and the state assumed sovereignty over urban areas and rendered permanent the divergence in their respective organizational ethos. This led to the recurrent reproduction of a tribal polity through differentiated norms of political socialization and civic practices, which sustained the self-exclusion of tribes from full participation in a modern urban-based civil society. Instead, this tribal polity formed its own rural-based "civil society" through ascriptive membership - not on elective criteria as in the urban sector - which is characterized by primordial loyalties circumscribed to a kinship-bounded radius of social trust and cooperation. Moreover, shaykhs assume their traditional leadership role through hereditary succession and not through election or meritocratic considerations as is the (not always respected) norm in modern civil society. Furthermore, while the tribes' primordial boundaries (territorial and genealogical) promote an intracommunal cooperative ethos, they also nurture a fierce parochialism, which engenders a reflexive antagonism toward outsiders that is not conducive to sustaining the value of social tolerance (ideally) associated with civil society. Although tribes have elaborate rules for conflict resolution based on "tribal customs" (al-'urf al-qabalī) within and between tribal polities, such rules are not transferrable to an urban context regulated by modern judicial practice (qānūn). Also, there is the divergence in cultural ethos: Tribes are rural guardians of ancestral traditions pre-dating state formation, and not modern citizens upholding a civic culture within the state. Given this set of particularities, Carapico [51, p. 323-5] suggested that civil society be categorized differently in terms of its domains of intervention and its primary social agents: In the rural areas the type of self-help community activism is best described as al-mujtama' al-ah/i (primordial affiliations-based civil society) that is initiated by agrarian actors with locally raised funds or remittances; ${ }^{9}$ while in the modernizing urban areas it could be described as al-mujtama' al-madani (citizens' rights-driven civil society) and is led by middle class change agents who are dependent on foreign funding.

The resulting spatially-based divergences in social practices and political organization are not due to the intrinsic cultural inertia ascribed to traditional polities, but the result of the state's chronic neglect of rural development, which dissuaded rural population from abandoning their traditions of mediation and self-help between primary associations (i.e., families, tribes, and villages). Indeed, the persistence of this rural-urban division is partly a consequence of the state's initial administrative weakness that led to the relegation of its authority to primordial leadership. The initial administrative weakness of existing state institutions was subsequently replaced by a largely dysfunctional bureaucracy devoid of effective service delivery capacity, which consolidated rural residents' sentiment of passive state avoidance into active state rejection [55]. The ultimate legacy was the consolidation of a hybrid national polity based on a rural majority of tribal members and an urban minority of state citizens. This hybrid polity was left to fester as the state's deliberate evisceration of modern institutions of intermediation (e.g., local councils, civil society organizations, etc.) to

\footnotetext{
9 These rural civil society organizations were epitomized in the Local Development Associations (LDAs), which began in 1963 on the basis of remittances from rural émigrés to Saudi Arabia. They consolidated the rural areas' political sovereignty, and institutional independence from the state, and thus indirectly challenged the state's economic relevance (see phase 2 in Table 1). Different regimes have sought to coopt their economic independence and political autonomy [27, p. 57-74]. In the 1980s, the Șâlih regime enacted a series of laws and decrees that coopted the LDAs' "civic activism" by merging them with local administration into "Local Council for Cooperative Development" - the precursors of today's Local Councils. In effect, this transformed an autonomous community cooperative movement into a "corporatist project of the state" (see [52, 53]). Their demise was occasioned by the 1990 Gulf war, which led to the expulsion of Yemenis and the end of remittances (see phase three in Table 1). These rural civil societies were replaced by urban-based NGOs largely dependent on international donors (see [54]).
} 
sustain its power, ultimately prevented the formation of a politically and socially integrated modern national polity.

This rural-urban spatial divide was replicated into a north-south geopolitical rift following unification in 1990 through the transfer of the north's primordial federalist socio-political order to the south. As Halliday [45] observed "Unity was... not a policy aimed at fusion but an instrument for inter-regime competition" (p. 38). The end result was the civil war of 1994, in which the north prevailed "by making significant concessions to the centrifugal forces": namely the main northern tribes and their militias, the army and Sunni Islamists who were agents of traditionalism. As al-Saqqaf [29] noted, unification was a political opportunity for the "renewal and expansion of traditionalism" throughout the southern territories (p. 100). Accordingly, they spread their consociational domination to the south along with their tradition-enforcing practices. Some of the effects include: (a) the de-cosmopolitanization of the urban milieu, especially 'Aden, through the prohibition of modern forms of entertainment (e.g., the closure of cinemas, the destruction of a beer factory, etc.,); (b) the promotion of qāt chewing as the hegemonic leisure activity and as the means of an assimilationist strategy to induce the cultural homogenization of the southern polity and expand the economic interests of the northern tribal qāt lords; ${ }^{10}$ (c) the Islamization of the public sphere through the segregation of the sexes, the enforcement of Islamic dress code for women, and the abrogation of liberal laws concerning women's rights; (d) the retribalization of the southern polity through the reinstatement of the tribal shaykh as the dominant communal authority figure and institution of local governance; and (e) the balkanization of the southern economy among the tribal-military-business cabal of the northern regime. These measures were compounded by the political exactions against, and material dispossession of, southerners, whose status as citizens was reduced to an unfulfilled aspiration. The result was the persistence of socio-political wounds

\footnotetext{
${ }^{10}$ These tribal qāt lords constitute an indispensable pillar of the cabalistic state as the commodity they sell structures the functioning of the social order, and regulates the quotidian existence of the population. Qāt's mode of consumption through the collective chewing session has reduced the national polity into the voluntary inmates of a social panopticon under the shared supervision of the state and tribal qāt lords (see [35]). Moreover, they are part of the 9 per cent of landlords who own 65 per cent of Yemen's cultivated land area and produce 64 per cent of the country's total qāt production (see [56]).
}

that have never healed and were ultimately manifested into the demand for regional secession. ${ }^{11}$

Since then a Yemeni national identity has remained an unevenly shared symbolic property among the nation's regionally sundered polity. Indeed, the prevailing public concern is no longer about affirming the shared identity implied in the nation and state relationality, but about renegotiating the political relationship between the polity and the state.

\subsection{State Existential Practices: Regime Maintenance}

The legacy of the above processes was the saddling of the state with a litany of deficiencies: The non-availability of nationalism as a mobilization ideology, the persistence of centrifugal regional political forces against the unitary state, and the antagonistic demographic, cultural and geographic segmentation of the national polity. These compelled the state to resort to opportunistic regime maintenance strategies, among which two are worthy of note:

The first was the adoption of what I call the state's existential politics, or alternatively as Migdal [58] calls it, the "politics of survival" (p. 206-237). The latter term is widely used to describe Yemeni state politics, but it is not historically contextualized and rarely operationally defined in the Yemeni context. It refers to the state leadership's chronic recourse to an ensemble of tactical maneuvers aimed exclusively at regime maintenance in a political environment characterized by the "fragmentation of social control" between the state, its venal retainers (the principal ones being tribal shaykhs and their regional militias) and a politically indifferent population that is conditionally amenable to political mobilization through the state's episodic mass clientelism. This political situation in which important segments of the polity are unreliable supporters of the state led to a chronic paranoia among state power holders. This engendered a governance modality based on a pathological relationship between state and society that was manifested as follows: The permanent alteration of the priorities of state leaders from improving the polity's well-being to an exclusive concern with regime maintenance through elite

\footnotetext{
11 The final report of the National Dialogue Conference (NDC) [57] contains a "consensual vision on the roots and contents on the Southern issue". It inventories the grievances of the southern polity vis-à-vis the north along four dimensions: political, legal and rights, economic and socio-cultural (see p. 30-36)
} 
collusion; a style of state decision-making driven by constant short term tactical maneuverings to placate potential adversaries; the deliberate establishment of overlapping agencies with redundant functions and the recurrent shuffling of state agencies' leadership to prevent the emergence of alternative power centers to the state's executive branch; lax public sector supervision and control from above, leaving public servants free to use state resources for private ends; the preemptive de-institutionalization of the formal state through the deliberate weakening of the public administration's implementation capacity by means of the strategic use of non-merit-based appointment through the deliberate reliance on arbitrary criteria (e.g., political loyalty, relative incompetence and corrupt reputation) to select office holders; the tactical disabling of the human development institutions (e.g., all aspects and stages of the educational system) through regulatory neglect, funding deficit and intentional selection of inadequate management staff as a means of impairing their proper functioning and thus limiting the population's aspirational horizon; chronic absence of a commitment to institution-building beyond their formal establishment that leads to the perfunctory institutional processing of the nation's population with minimal improvement in its well-being; and policy-making and/or problem-solving was prey to an endemic strategic paralysis due to an intrinsic contradiction between the executive branch's advisers' political imperative of maintaining the regime in power, and the line ministries' technocrats' policy priority of addressing the nation's massive development deficit.

The second was the institutionalization of the principle of subsidiarity as a center-periphery governance strategy. The first use of the subsidiarity principle was by necessity in the aftermath of the 1962 revolution given the state's administrative weakness. Subsequently, during the 1980s it became de facto state policy that was tactically deployed as the state weaned itself from its fiscal dependency on the rural population due to the availability of carbon rent. By the 1990s, the state's complete fiscal autonomy from the population was consolidated into the strategy of monopolizing control of the center and resource-rich parts of the periphery while authority over the rest was shared with, if not relegated to, regional primordial elites. In practice, the subsidiarity principle is a tactical decentralization of power through the establishment of a vertical relationship between the state and regional tribal fiefdoms. In effect, the state abdicates its responsibility toward the majority of the national polity through shared territorial managerial responsibility with elite corporate groups. It exemplifies a form of indirect rule by the Yemeni state, as local authority is delegated to traditional elites, which entrenches primordial rule and feudal privileges in the rural areas. Consequently, subsidiarity entails a set of organizing principles that configures asymmetric relations between the state and the national polity: (a) the articulation of state-society relations around the hierarchical ranking of the polity's constituent groups based on their political threat level to the state; (b) the maintenance of political stability and loyalty through the delegation of authority to geographically bounded regions or sub-regions under the political control of state-funded shaykhs, or under the surveillance of a military division and social policing of a sectarian group (e.g., the Salafists in the northern Zaydī stronghold of Șa'ada province); (c) the cartelization of power through the establishment of shadow parastatal structures as an architecture of governance that privileges social groups with high threat quotient and substitutes elite reciprocity for public accountability; (d) the tactical relegation of the formal state to a subordinate managerial entity saddled with functionally disabled ministries, while national affairs are actually managed by the patrimonial core of the shadow state in coordination with its cartel of clients; and (e) the permanent institutionalization of the stipendiary regime served as a means of financing this selective decentralization arrangement and as a rural redistribution scheme for social welfare of the included tribal constituencies.

The institutional ecology created by the state's regime maintenance practices was not conducive to the proper institutionalization of electoral politics when the 1970 ban on the formation of political parties was lifted in 1990. Indeed, it inaugurated the shift from elite patronage to mass clientelism. The example was set with the initial establishment of the General People's Congress (GPC) in 1982 and its subsequent consolidation into the ruling political party after unification into a "clientelistic party" that bribed its political supporters, and never made the transition onto a "programmatic party" that promotes social programs for the provision of public goods [59, p. 87-8]. Other political parties (with the partial exception of the Islamist party al-Ișlāh, which used charitable activities to foster political support) adopted the practice of bribing political supporters to level the playing field. Moreover, they had to negotiate their existence with the state and to submit to its rulebook of negotiated cooptation. Indeed, electoral politics were driven by an opportunistic alternation among oppositional parties between contestation and accommodation to the state. Accordingly, elections were reduced to a mechanism for elite entrenchment not democracy enhancement 
and all political actors capitulated to "the politics of positional change and not structural reform" [60, p. 80]. As a result, change of the societal and political status quo was impervious to elections, and politics as a public discourse was emptied of its residual credibility and accountability.

These practices became an integral part of the state's institutional mechanism and ultimately transformed the country into a libertarian dystopia: That is, a social order without formal regulatory institutions, lacking third party legal protection given the absence of an independent judiciary, and guided by a socially extreme laissez-faire ethos that delegates the management of citizens' interaction to traditional communal authorities. This societal arrangement engendered an administrative culture labelled "northern anarchy" (al-fawḍ̄a al-shimā/I), which is characterized by a state bureaucracy that is merely a patronage distribution mechanism devoid of any developmental compass, and that selectively co-opt the society's elites into its service on a rotating basis contingent on the political urgency of the moment [39]. Consequently, this established by default an anarchic mechanism for regime change, which operated as follows: The state concedes authority to tribal shaykhs over their regional fiefdoms while it foments competition between them as a means of containment, which sustains the latent centrifugal tendencies within the national polity. In this way, these potential political contenders for state power are constantly preoccupied with ensuring the security of their tribal fiefdoms to challenge the center. However, when the center can no longer contain these peripheral forces (either militarily or through bribes) the result is the takeover of the state by a regional tribal militia, as happened on 21 September 2014 when the Hūthīs took over Șana'â'.

\subsection{Governance Culture: Venal Polity Reproduction}

The culture of governance is constituted by the cumulative institutional effects of the practices discussed above: The political elite's self-serving use of a nationalist discourse, the chronic absence of an effective strategy for national subject formation and territorial integration, the mass exclusion of citizens by the state's elite-centric policy regime, the marginalizing administrative practices towards regions and communities, and the inequitable and polarizing selective patronage and occasional clientelist political practices, which were exacerbated by external political and economic interventions. The resulting governance culture never operationalized symbiotic relations between the state and its citizens. Instead, it had corrosive effects on citizens' behavioral ethos: It undermined their affiliative sentiment toward the nationstate; constrained their political agency within the public sphere; weakened their civic disposition towards fellow citizens; limited the scope of their civic engagement; and diminished their attachment to a national identity. This governance culture led to the corruption of public values as manifested in the endemic accommodation to state-society relations characterized by a pervasive transactional ethos and the corollary submission to the state's political cooptation and inducement to self-entrapment through acts of petty corruption.

Indeed, the regime's compulsive "opportunistic patronage" of the polity engendered a decentralization of corruption from an elite-exclusive practice to its generalization into a mass-inclusive culture. This generated a malignant synergy between a cabalistic state and a venal polity through the proliferation of venal mechanisms of mediation that promoted a culture of corruption, which permeated the entire administrative apparatus of the state and spread throughout society. Indeed, the state actively fomented a venal polity as its self-reproduction mechanism through normalizing corruption into an irresistible social gravitational force: (a) by condoning elites' use of the state as a public means to private ends; (b) by inducing citizens, by means of elite exemplification, to appreciate corruption as an essential means to social mobility; and (c) by normalizing the public's expectation of payment for the performance of their civic duties. This is confirmed by the fact that in 2016 Yemen was ranked 170 out of 176 countries in Transparency International's Corruption Perception Index. In the MENA region, Yemen "has the highest bribery rate, with nearly four in five public service users paying a bribe (77 per cent)" [61, p. 31]. ${ }^{12}$ This culture of corruption's operational norms have entangled the national polity within a complex web of venal practices, which have become the normal means for (a) accessing public services as an ordinary citizen, (b) performing work-related tasks as a civil servant, or (c) asserting one's political agency as a member of civil society. ${ }^{13}$ The ethical challenges and agential

\footnotetext{
${ }^{12}$ According to the Transparency International report [61], Yemeni citizens' "perception of corruption by actors" in ten institutional sectors is overwhelmingly negative: Prime Minister's office $(49 \%)$, parliament $(77 \%)$, government officials $(79 \%)$, local councilors $(51 \%)$, police $(74 \%)$, tax $(83 \%)$ judges $(60 \%)$, traditional leaders $(68 \%)$, religious leaders $(16 \%)$, and business executives $(37 \%)$ (p. 30,33$)$.

${ }^{13}$ The public's complicity with the state's culture of corruption is not due to the lack of "awareness of citizens about their rights and the legal framework to
} 
dilemmas associated with these three roles are briefly illustrated below.

First, ordinary citizens are confronted with the prevalence of personal mediation in interacting with the state that invalidates the notion of its obligations vis-àvis citizens, as it takes the form of a supplicant relational protocol, (i.e., favor-seeking and bestowing) between citizens and bureaucrats in government institutions. Such a relationship is transacted through the following practices: The baghshish syndrome, which is a generalized system of citizen harassment through petty bribes seeking, taking and giving, in which government service delivery entails a conditional quid pro quo involving cash payments to civil servants. And the other is the wāsta system (an endemic Middle Eastern practice), which citizens must resort to when petitioning for a public good that entails the obligatory intercession of a socio-politically connected third party (as political philanthropist) to enhance their chances. This confirms the relational axiom within the corporatist state: "individuals... do not interact with the state directly, but through intermediaries" [62, p. 184].

Second, civil servants, perhaps animated by economic necessity or engaged in elite emulation, are entirely motivated by a pecuniary ethos. This has a corrupting effects on their work ethic as they expect to be compensated regardless of performance. This is evident in the fact that "around a third of all public sector workers are ghosts, that is, they do not turn up for work, but draw pay" [63, p. 24]. Moreover, the introduction of an incentive system (al-mukāfāat wa alhawāfiz) within the civil service law that sought initially to improve the performance of civil servants, has deteriorated into an entitlement system that serves the state's cooptation strategy. This contaminates the value framework of the public sphere by discouraging virtuous behavior among public servants, corroding the moral content of government action, and fraying the nation's ethical seams. ${ }^{14}$

fight corruption", but because of the pervasive coercive situational imperatives they confront when working in, or interacting with, state institutions. This suggests that the widespread belief that "ordinary people can make a difference in the fight against corruption" is merely a comforting delusion given that the leadership of national institutions are the main corruption enablers.

14 In this context, even the salary paid to civil servants is a form of patronage similar to the stipend paid to tribes. This is illustrated in the fact that the government's wage bill for the 1.25 million civil servants (and their estimated 6.9 million dependents, which together makes up 30 percent of the
Third, members of civil society in their quest to exercise their socio-political agency are subjected to cooptation pressures from the three main funding sources: From the government through its sponsorship of civil society organizations (CSOs) in order to turn them into proxy mechanisms for citizen cooptation and voter mobilization. The same tactic is employed by the main opposition party (al-Ișlāḥ) through the guise of charitable works. Also, UN agencies and Western governments have subordinated CSOs' agency to that of mere sub-contractors for their political liberalization schemes and development projects. This partly explains the surge in the establishment of these organizations throughout the country: From 424 in 1989 to 12,317 in 2012 [54, p. 11]. As a survival strategy most, if not all, CSOs in Yemen have become willing clients imbued with a mercenary ethos on behalf of the above parties' interests. ${ }^{15}$

In sum, the previous sub-sections analyzed the contingent combination of historical factors and social forces embedded in local and regional processes that fashioned the constitution of Yemen's political system into a hybrid of endemic elite patronage and episodic mass clientelism. This political system is the legacy of a path-dependent process that resulted from state policy decisions made in response to socio-political challenges that have sedimented into patterns of institutional arrangements and of state governance practices. In turn, these have circumscribed the society's historical trajectory, determined its statebuilding strategy and its polity formation process, as well as influenced citizens' political subjectivity and agency. All of this culminated in the contemporary Yemeni state that I called a cabalistic corporatist state, which dissolved national affiliative sentiment into regional and communal ones and bequeathed a minimally shared national identification among the citizenry.

Table 2 categorizes the components that articulate the immanent logic of the cabalistic corporatist state. ${ }^{16}$ It presents a paradigmatic description of the nature of

total population) amounts to 65 billion Yemeni Rials a month [64]. This sum amounts to 31 percent of the state's budget and to over 11 percent of GDP [65 p. 6 and 144].

15 This is corroborated by a survey that found "Approximately $50 \%$ of respondents believe... the CSOs are only a means to obtain money from foreign institutions" [66, p. 26].

${ }^{16}$ The table is based on my long-term experience in Yemen as a United Nations staff, resident scholar and a critical engagement with the following works: $[26,50,59,67,68]$. 
this state's structural logic and operational norms that underpin its governance practices. The demise of this state, as captured in the slogan al-sha'ab yurīd āsqat al-nidhām ("the people want the fall of the system"), was the motivating aspiration for Yemen's Arab Spring. Paradoxically, the beneficiaries of this state (e.g., leaders of regime-embedded political parties and their recruits) were the majority members of the National Dialogue Conference tasked with hammering out a vision for a "New Yemen". Again, the process ended in premature failure as was the case in the 1962 and 1990 attempts at nation-state building. This is discussed in the last section.

Table 2: Yemen's Cabalistic Corporatist State

\section{Norms, Structure and Practices}

The state's infrastructural constitution is described below along four dimensions that make-up its culture of governance. First, under the rubric of "governance norms" the state's operational modality is inventoried in terms of six aspects that collectively define and structure state relations with the national polity. Second, the term "selection criteria" refers to the individual or group assets prioritized by the state in allocating patronage privileges. Third, "membership categories" is the classification of the polity according to their social make up and political functions in the cabalistic state. And fourth, the domains of patronage and clientelism identify the key sectors and the beneficiaries of what I call the hybrid regime of elite patronage and mass clientelism.

\section{Governance Norms: Polity Regimentation}

- Political Culture: State politics is based on a national polity cooptation strategy organized around selective elite patronage through rent distribution and/or extraction and episodic mass clientelism (i.e., votes-buying during elections), which veneers the state's political legitimacy. Political stability is obtained through the financial cooptation of national/communal elites, instead of political bargaining with their constituencies. As a rule, elite grafting is ignored while mass poaching of state resources is tolerated as a means of entrapping the state-orphaned polity into a culture of corruption. The latter perverts the citizenry's civic sensibility through its involuntary complicity with the state's predatory practices.

- Administrative Ethos: There is no separation between politics and administration as the shadow state dictates the managerial functions of the formal state's administrative agencies. For example: the executive branch selectively delegates state functions to primordial regional actors; the judiciary auctions justice to the highest bidder; the legislature is a venue for bargaining over the preferences of the executive and the personal interests of legislators; the bureaucracy's primary function is to serve as a salary distribution apparatus; the ministries are institutionally unable to address societal challenges, and thus ministers attend to administrative routines and ceremonial functions, as their ultimate role is to serve as the institutional alibi of the shadow state.

- Structural Exclusion: The differential privileging of societal groups and the asymmetric distribution of state resources engendered the structural exclusion of the mass of ordinary citizens. Their fate is relegated to the haphazard attention of marginal local/regional stateappointed bureaucrats and the opportunistic leadership of tribal shaykhs. The majority of the polity is denied substantive participation in the elite-centric mechanisms of decision-making over the nation's fate. This exclusion is relieved by the regime's mass clientelism strategy (a) through perfunctory participation in elections induced by cash distribution; and (b) through haphazard welfare initiatives by the state bureaucracy such as the state's food and fuel subsidies, and occasional recruitment as state employees.

\section{Selection Criteria: Elite Constitution}

- Mobilization Capital: Possession of significant political influence over different segments of the polity, but especially over rural constituencies given the predominantly rural location of the national polity.

- High Threat Quotient: Groups endowed with the potential to threaten the regime's hold on power in an endemically conflict prone socio-political context due to the absence of state monopoly over the use of arms. They are co-opted through paid "protection pacts" with the regime.
- Institutional Ecology: The state's institutional architecture and operational logic suffer from an intrinsic structural asymmetry. This is established in a bifurcation between the government (al-hukūma), which represents the visible state apparatus made up of appointed cadres, and the power (al-sulta), which is the shadow state constituted by members of the patrimonial elite (see below) who control everything. Consequently, the institutional ecology is fractured into endemic antinomies of governance: nation vs. state formal state vs. shadow state, power elite vs. government elite, elites vs. ordinary citizens, executive branch vs. line ministries, center vs. regions, institutions vs. society.

- Social Mobilization: In the absence of any viable political ideology to harness the public's support, the regime resorts to the segmentation of the polity into groups according to their degree of political relevance or threat potential. This is pursued through (a) the contingent hierarchization of societal groups and their organization into a series of discrete silos of vertical power relationships that ensure mutual loyalty and dependency on the President and his patrimonial entourage as well as structure these groups' competition over rent allocations; and (b) recourse to shared governance with regional actors through the strategic use of the principle of subsidiarity to selectively delegate power (see text).

- Political Financing: To sustain its political stability the regime pursues a three-prong political financing strategy: (a) the establishment of rent distribution networks, which circulate "carbon rent" among an exclusive group of potential political challengers as a means of their cooptation; (b) the sponsorship of an economic elite (crony capitalist class) as a means of piggy-backing on their wealth-creation activities through compulsory partnerships or "fiscal contracts" with next of kin of the head of state or their allies; and (c) the mobilization of "aid rent" from the international community (i.e., UN agencies and bilateral donors) as the exclusive funding source of "development" projects, which employ and thus depoliticize the foreign educated upper middle class.

- Strategic Assets: Embodied capital in targeted societal actors that the state uses for its contingent purposes: e.g., symbolic capital, international reputation, familial status, business skills, etc.

- Domestic Balance of Power Capability: Potential to contribute toward stability or instability, when requested by the regime, within the state-managed, but intrinsically unstable, coalitional politics of competing factions and regions. 
- Patrimonial Core: Exclusive network of the head of state's immediate and extended family members (most with military background) and tribal associates, who are allocated the most strategic posts in the political, military, security and economic sectors The members of this tribal-military-business network constitute the corporatist cabal that runs the "shadow state", and is the ultimate repository of power in Yemen.

- National/Regional Elites: Opportunistic assemblage of merchants, large landowners, bankers, and industrialists whose material assets, economic know-how and political vulnerability can be manipulated to induce collaboration with patrimonial core members. Also included, are the dynastic political and tribal families who are conferred political entitlements as ministers, advisers, etc.

- Rural/Communal Leaders: Primarily tribal shaykhs whose "oligopoly of mobilizational capability" over the rural polity forces the state to rely on them for control of the rural population as well as its mobilization on behalf of the regime when needed in situation of conflict or during elections.
- Urban Middle Classes: Composed of educated professionals who staff the state bureaucracy; religious scholars that could issue regime-friendly fatwas; secular intellectuals who supply journalistic defense of the regime. They constitute the clientelist stratum that provides the symbolic resources to prop-up the regime's legitimacy deficit, and they substitute for the regime's need of popular support. There is a minority within the middle classes that include the political dissenters: journalists, writers, activists, and CSOs. The latter are readily instrumentalized as state-sponsored partners in charitable activities, or as foreign-funded agents of political liberalization, which undermines their institutional consolidation into legitimate counter-status quo political actors.

- Marginalized Groups: All those whose "threat quotient" is perceived by the state as low or non-existent. They include: the rural and urban poor, ethno-linguistic minorities, women, students, and above all the youths who constitute the majority of the national polity.

Patronage and Clientelism Domains: Kleptocratic Redistribution

- Military/Security Apparatus: Exclusive recruitment from kinsmen of patrimonial core and related tribes for the officer corps of all the branches of the military and security services; rural recruitment of foot soldiers as an employment scheme for ordinary tribesmen who serve as regime's rural voters bank.

- Private Sector: Allocation of sectoral monopolies, and exclusive licenses for import of specific commodities and the provision of certain services; granting privileged access to loans from government-linked banks; selective distribution of tax-exemption privileges and government contracts for public works, etc. These transactions have reduced the national economy into a rent extraction niche.
- Public Sector: Job bank for middle classes in cities and provincial towns, who serve as neutral buffer in urban politics by being legally mandated to stay out of partisan politics, and as a captured electorate for the ruling party. They constitute a reservoir of guaranteed supporters during elections.

- Politics: Proportional distribution of offices to representatives of corporatist factions; opposition political parties are constrained to negotiate a strategic collusion or tactical alliance with the state's ruling party; and competitive votes-buying, or political bribery, is the primary means of inducing the citizenry's civic engagement.

\section{TRANSITION: DEVOLVING THE STATE AND REGIONALIZING THE NATION}

The cumulative impact of the state's existential politics that benefitted the elite segment of society was the undermining of the consolidation among the national polity of a shared sense of collective belonging to a unitary nation-state. This endemic belonging deficit was exacerbated by the regime's power-maintenance strategy through the systematic pursuit of short-term tactical advantage at the expense of the national polity's cohesion. The end-result was the chronic socioeconomic disenfranchisement of non-elite groups, and the permanent political marginalization of some regions of the country, which sundered the nation into an archipelago of politically alienated regional enclaves. In such a context, democracy atrophied into a procedural ritual (periodic elections and popular suffrage) and never fulfilled its substantive promises (freedom of political agency and enhanced well-being). The case of Yemen suggests a political axiom: Nation formation is contingent on an enabling state formation process. Indeed, the Yemeni state, initially by default and subsequently by design, provided a disabling environment for its own institutional development. This contributed to its failure to constitute a national polity based on equal citizenship, which undermined its legitimacy and engendered an ambiguous loyalty toward it as manifested in the widespread demand for regional autonomy. In effect, the Yemeni state never institutionalized the nation and never integrated its regional formations; and thereby condemned national polity members into straddling incompatible political identities and agencies: Citizens of a republic, or tribesmen of separate regional shaykhdoms. Consequently, the contemporary political situation is one characterized by persistent tribalism, endemic regionalism, and resurgent sectarianism. Indeed, Yemen is in the throes of a transition process of uncertain destination. Below, I describe the forces that initiated the transition and their effects, before discussing the failed attempt at bringing it to a closure.

\subsection{Yemen's Arab Spring: Centrifugal Forces Unleashed}

The alienated political relationship between citizens and the state, which is the legacy of over a generation long experience of misgovernment, provided the catalyst to Yemen's Arab Spring. The latter is the 
umbrella term used for a triad of simultaneous rebellion that inaugurated the implosion of the cabalistic corporatist state:

- Shabāb al-Thawra: The emancipatory social movement of Yemeni youths whose "revolution" was catalyzed by the Tunisian example, but was locally animated by their chronic exclusion from the state's policy considerations and whose future under the regime promised permanent social exclusion and economic marginalization [69].

- Al-Hirāk al-Janūbĩ: The southern separatist movement, which started as a quest for social justice on behalf of former officers in the southern military and mutated into a secessionist movement on behalf of the entire southern polity. The latter's incorporation into the national polity was through what they perceived as a colonization process that relegated them to the status of second class citizen, and whose persistent demand for social inclusion was ignored by the regime [70].

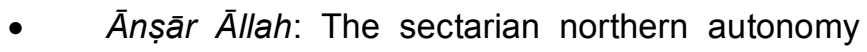
movement of al-Hūthī who embodied the Zaydī's doctrinal commitment to khurūj, i.e., rising against an unjust ruler. Their political discontent, which was already simmering from long-held resentment towards the state's non-recognition of their distinctive religious creed and for its support of a Saudi-backed Salafist "invasion" of their region, was catalyzed into public protest, and ultimately military insurgency, by the regime's collaboration with the United States' war on terror [71].

The significance of the Arab Spring was its promise to engender the demise of the region's exceptionalism in terms of its stereotypical representation as a political and cultural milieu inimical to the viability of modern democratic institutions of governance, given its association with the millennial tradition of tribe-centric patriarchal regimes and their polities' chronic accommodation to the pathological rule of autocrats. Its ultimate failure in Yemen, especially of the youth movement, was not because of the intrinsic unreceptivity of Yemenis to societal transformation, but due to their low "threat quotient" to the state power holders and their inherent susceptibility to the opportunistic intervention of the same reactionary corporatist forces (i.e., the tribal confederations, the army and the Sunni Islamists). These reactionary forces undermined the modernist aspirations of an earlier generation of revolutionaries, and subsequently transformed the 1990 unification into an internal colonization process, and again have thwarted the emancipatory aspiration of the Arab Spring's youth in the twenty-first century [72]. As one scholar aptly observed: "Yemen's Arab Spring was more an internecine fight between regime elites than a popular revolt that deposed a dictator" [73, p. 3]. In contrast, the persistence of the other two movements suggests the ultimate vulnerability of the cabalistic corporatist state and its political system of endemic elite patronage and episodic mass clientelism when confronted with armed insurrectionary movements whose leadership could not be co-opted. Paradoxically, the "success" of these two armed movements have unleashed the centrifugal forces that have been contained since the civil war of 1994; thereby opening Yemen's own Pandora's Box.

There are three centrifugal tendencies that were embedded in the state formation process in Yemen, and that are now unchecked and thus could engender the profound social, political and geographical reconfiguration of the country as highlighted below:

- Tấ'ffiyya (sectarianism): The re-imposition of the sectarian territorial division that prevailed under the Imamate between "Upper Yemen" (al-Yaman al-'alā) and "Lower Yemen" (al-Yaman al-asfal), which articulated the subordinated relationship between the population's two dominant confessional allegiances - the minority northern Zaydi and the majority southern Shāfi'T. This socio-geographic configuration is being entrenched by the Hūthīs' regime maintenance practices that not only promote a sectarian solidarity as a political mobilization strategy but also seek to re-establish the primacy of a confessional identity over a national one: The restoration and semantic revision of the antagonistic genealogical bifurcation between the descendants of 'Adnān (as ordained rulers of Yemen) and those of Qahțān (as sociopolitical subordinates of northern Arabs); the public display of posters of political leaders of Iran and Lebanon as the new icons of political allegiance; the instrumentalization of the public performance of Shī'a religious rituals into mass spectacle of political intimidation; the recourse to a primordial discourse of social hierarchy between the Hūthī elite and the rest of society, as exemplified in the invocation of the reverential title of "Sīdī" or "al- 
Sayyid" in referring to the Hūthī leader and in the frequent use of status distinction epithets to enforce political subordination such as al-qanādīl (to refer to the Sāda as enlightened leaders) vs. al-zanābill (to refer to the non-Sāda population as deferential followers); and the dissemination of Zaydi religious doctrine as a means of political conversion of youth, women and military personnel of the former regime into adherents of the Ḥūthī cause [74, 75].

Infișāliyya (secessionism): The rekindling of the deeply felt sentiment of political incompatibility entrenched within the north-south geographical division engendered by the perceived colonial annexation of southerners as second class citizens following the civil war of 1994, and its symbolic enshrinement in the dahbāshì syndrome according to which the north is perceived as a culturally backward tribal enclave, in contrast to the south as a culturally urbane milieu. The endemic use of this term served to sustain a distinct South Yemeni identity under northern domination.

- Manātiqiyya (regionalism): The spreading demand for autonomous regional formations. Worthy of note is that regionalism once symbolized a provincial chauvinism that was deployed as a strategy of rule by the north to assert its "ethnoterritorial" primacy over the nation, is being re-appropriated as a rationale for dissent and justification for the pursuit of regional autonomy. This quest for regional autonomy reflects not only an endemic resistance to being subordinated to the north-dominated cabalistic state, but also a strong desire for separate regional identifications based on distinctive confessional or cultural factors over a national identity that since unification was assimilated into an exclusively northern tribal identity.

Equally alarming is the emergent phenomenon of "ethno-national othering" between ordinary citizens from the north and the south as if they belong to an alien ethnicity and nationality. This practice originates from a synergy of the three centrifugal forces sectarian polarization, regional identification, and national separation - and is leading to a secessionist nationalism especially among southern residents. It may become an unsurmountable obstacle to sustaining the unitary nation-state as it seems animated by a combination of hostile sentiments: Revanchist animosities based on memories of their colonizing experience with the north and the resulting lack of empathy with northerners; and political resentment towards people from the north for their unwitting accommodation with the Hūthīs. Consequently, northerners are no longer seen as people of the same nation, and whose entry into the south is now being regulated and who are ostracized when encountered by people from the south [76].

\subsection{The NDC: "New Yemen" Stillborn}

The antidote to these centrifugal forces was supposed to be the Comprehensive National Dialogue Conference (NDC), which was held from 18 March 2013 to 21 January 2014. According to the rather hyperbolic declaration in the Final Communiqué, the gathering "provided a unique forum of its kind, and an unmatched political process which has no precedence in the history of Yemen neither the entire Arab region". It was a "great national feat", which "became the most prominent political transition in terms of participation and transparency in the Arab region" [77]. To be sure it is not the first such national dialogue in Yemen's history, as it is an established tradition of resolving conflict or addressing issues of national importance that inaugurated the perennial, and still unfulfilled, quest for Yemen's socio-political modernization since the 1930s [78]. Hyperbole aside, the process itself was an achievement. In spite of the praiseworthiness of its process, the NDC was first and foremost the brainchild of stability-conscious regional monarchies and securityminded Western capitals that culminated in the "Gulf Cooperation Council Initiative" and was supported by a coterie of donors known as the "Group of Ten" [79]. Therefore, the NDC was a strategic attempt to co-opt the youth-led movement by diverting their street protest into a negotiation process under the leadership of the Șana'â'-based members of the cabalistic state's patrimonial core and their political clients. ${ }^{17}$ Indeed, it exemplifies the elite-centric political decision-making culture of the cabalistic state.

\footnotetext{
${ }^{17}$ This is evident in the fact that the majority (68 per cent) of the 565 conference delegates (nearly double the members of Yemen's parliament: 301 ) were members of regime-colluding political parties, and whose involvement with the larger public is largely through clientelistic practices. More telling is the fact that the overwhelming number of youths who participated in the NDC were not independent but were affiliated to parties: 105 out of the 145 seats reserved for youths. Moreover, the organization of the NDC betrayed the opportunistic patronage ethos of the cabalistic state, as each delegate received a daily stipend averaging $\$ 2,600$ a month, which exceeded the annual GDP per capita of $\$ 1,473$, and thus suggests a form of political bribe to induce citizens' participation and acquiescence.
} 
Nevertheless, its lexical choices broadly captured, or more aptly pandered to, the aspiration of the Arab Spring's youth. As the Communiqué puts it: Its deliberation sought "to create a participatory future that draws new foundations for a modern civil Yemeni state" that is based on "a new social contract for Yemen", which represents an "irreversible emancipation" from the past and "lays the ground for a rebirth of our people", while restoring "the confidence of the people in the State" [77]. More importantly, the NDC Communiqué is replete with critical acknowledgements of the state's multiple failures and that highlight its capture by cabalistic forces: "We are fully aware that the absence of effective institutions of government allowed the penetration of narrow interests of the few to control and manipulate and even seize power to serve their goals and ends". And it recognizes that the devolution of the state is the ultimate solution to Yemen's current centrifugal political tendencies: "The transfer of powers and responsibilities from the center to the new regional authorities will put an end to the monopoly of power, will ensure equitable distribution of wealth and brings the institutions of governance closer to local communities". This would establish "a climate of trust between citizens with each other, and with public institutions".

As in the past when state-building in Yemen became entangled in regional political conjunctures with unintended consequences for the nation's fate (e.g., 1962 and 1990). Again, in 2013 when the NDC was launched, the country was entangled within a historical conjuncture configured by the contradictory interests of international, regional and local actors: (a) the security anxieties of the US-imagined "international community" animated by its partly self-inflicted war on terror, (b) the sectarian animosities between Saudi Arabia and Iran competing for regional hegemony, (c) the political machinations of rival northern-based elite factions over the re-apportionment of power, and (d) the youths' emancipatory expectations induced by the Arab Spring. The denouement of the negotiations over these interests ultimately derailed the national reconciliation process and accelerated the disintegration of the national polity. The plenary consensus that could not be achieved through public deliberation over the final architecture of Yemen's federal system during the NDC was replaced by political bargaining among the twenty-two member Regions Committee. The decision that was announced in February 2014 to establish a federal system composed of six "new regional authorities" was the catalyst to the unravelling of the NDC's aspiration for a
"New Yemen". ${ }^{18}$ It was promptly rejected by the main stakeholders, al-Hirāk and al-Ḥūthīs among others, who saw it as an attempt by northern elites to maintain their monopoly on power. In contrast, it was agreed to by the governing party (the GPC) and by the main opposition Islamist party (al-Ișlāḥ), which are opportunistic colluders as they are both opposed to the separation of the south and the autonomy of al-Hūthīs in the northern province of Sa'ada. Indeed, the federal structure seems to be an elaborate cartographic manipulation, and administrative re-engineering, of the nation-state's political geography, which would have had the following, perhaps intended, ramifications: (a) to contain the political self-determination of both the northern and southern movements; (b) to suppress other regions' aspiration for autonomy (e.g., Hadramawt, Soqotra); (c) to entangle decision-making within the politics of bureaucratic infighting that would be engendered by the new federal administrative superstructure; and (d) ultimately to sustain the dominance of the cabal of northern elites and their regional allies that constitutes the tribal-militarybusiness complex [80].

The political opposition to the federal system's structure led to three fatal events: (1) on 3 January 2015 the Hūthīs forcibly prevented the formal presentation to the President of the final draft of the new constitution for a federal state, as the Chairman of the NDC was kidnapped on his way to deliver the document; (2) on 6 February 2015 the Hūthīs formalized their take-over of Sana'â' with the establishment of a Revolutionary Committee as Yemen's governing body; and (3) on 25 March 2015 (five days after the Hiutthīs captured Aden) Saudi Arabia launched its war on Yemen. Since then Yemen is embroiled in both a civil, and inter-state, war that has eradicated over half a century of relative developmental

\footnotetext{
${ }^{18}$ Yemen would be renamed the Federal Republic of Yemen, to be composed of six regions encompassing the 22 provinces, and which would be organized along a north-south axis that replicates the country's division prior to unification. There would be four regions in the north and two in the south. The four regions of the north and their constituent provinces are as follows: (1) Āzāl: (capital city Șana'ā') Șa'ada, 'Amrān, Șana'ā' and Dhamār; (2) Sabā: (capital city Mā'rib) Al-Jawf, Mā'rib, and al-Bayḍā; (3) Al-Janad: (capital city Ta'iz) Ibb and Ta'iz; (4) Tihāma: (capital city al-Hudaydah) Haja, al-Maḥwīt, alHudaydah and Raymah. The two regions of the south and their respective provinces are as follows: (5) 'Aden: (capital city 'Aden) al-Dal'i, Lahij, Ābyan and 'Aden. And (6) Haḍramawt: (capital city al-Mukallā) Shabwa, Haḍramawt, al-Mahrah and the Soqotra Archipelago. The city of Șana'ā' will have a special status in the Constitution to guarantee its independence and impartiality vis-àvis all other regions. Also, the southern port city of 'Aden will be given independent legislative and executive powers.
} 
progress through: (a) the systematic destruction of its social infrastructure (e.g., roads, schools, health centers, factories, marketplaces and civilian residences); and (b) the generational loss of human development through demographic attrition resulting from war-induced mass internal displacement, mass external migration, mass impoverishment, chronic malnutrition, rampant spread of diseases and thousands of deaths. With 'Alī 'Abdāllah Șāliḥ's killing on 4 December 2017, Yemen's formerly manageable political tensions have fractured into irreconcilable antagonisms.

There is a historical irony in the trajectory of the emergence of the modern state in Yemen. Its inaugural moment occurred in the midst of an Arab Cold War that pitted the revolutionary Egyptian republic against the primordial Saudi monarchy, which fought a proxy war in Yemen to determine whether its fate would be as a republic or a monarchy. This process is being reenacted in a new regional cold war between Sunni Saudi Arabia and Shīa Iran who are using Yemeni soil as the theater of a new sectarian proxy war. The first cold war ended with Yemen as a democratic republic, if only nominally. However, this new cold war has not only already rendered obsolete the federal state envisioned by the NDC, but also may lead to the demise of the Yemeni state in its current configuration through (a) the permanent restoration of the preunification north-south division, (b) the reinstatement of the Imamate-like theocracy in parts of the north, and (c) the creation of other regionally-demarcated political entities. Even if federalism is improbably adopted, the pervasiveness of the cabalistic state's venalitypromoting governance culture and its perversion of the nation's civic ethos will ensure the replication of its rent seeking economic practices and of its endemic culture of corruption within the federal regions and their constitutive provinces. Alas, Yemen has lurched into a socio-political wilderness with an inscrutable future.

\section{ACKNOWLEDGEMENTS}

The author expresses his gratitude to the many anonymous reviewers who have challenged him to substantiate his arguments.

\section{CONFLICT OF INTEREST STATEMENT}

The author affirms that he has no conflict of interest.

\section{REFERENCES}

[1] Harari YV. Sapiens: A Brief History of Humankind. London: Vintage; 2014.
Kerr MH. The Arab Cold War: Gamal 'Abd al-Nasir and His Rivals, 1958-1970. London: Oxford University Press; 1971.

[3] Badeeb SM. The Saudi-Egyptian Conflict over North Yemen, 1962-1970. Boulder, Colorado: Westview Press; 1986.

[4] Ferris J. Nasser's Gamble: How Intervention in Yemen Caused the Six-Day War and the Decline of Egyptian Power. New Jersey: Princeton University Press; 2013.

[5] Wimmer A, Feinstein Y. The Rise of the Nation-State across the World, 1816-2001. American Sociological Review 2010; 75: 764-790.

https://doi.org/10.1177/0003122410382639

[6] Peterson JE. Nation-Building and Political Development in the Two Yemens. In: Pridham BR, editor. Contemporary Yemen: Politics and Historical Background. London: Croom Helm; 1984

[7] Thomassen B. What Kind of Political Anthropology? International Political Anthropology 2008; 1 (2): 263-274.

[8] Elie SD. From Ethnography to Mesography: A Praxis of Inquiry for a Postexotic Anthropology. Qualitative Inquiry 2012; 19 (3): 219-231. https://doi.org/10.1177/1077800412466051

[9] Gramsci A. Selections from the Prison Notebooks, ed. Hoare Q., and Smith GN. London: Lawrence \& Wishart; 1971.

[10] Crehan K. Gramsci, Culture and Anthropology. Berkeley: University of California Press; 2002.

[11] Anderson B. Imagined Communities: Reflections on the Origin and Spread of Nationalism. London: Verso; 1991.

[12] Foucault M. Power/Knowledge: Selected Interviews and Other Writings, 1972-1977. New York: Vintage; 1980.

[13] Agamben G. Homo Sacer: Sovereign Power and Bare Life. Stanford: Stanford University Press; 1998. Agamben G State of Exception. Chicago: University of Chicago Press; 2005.

[14] Das V, Poole D. Anthropology in the Margins of the State. Delhi: Oxford University Press; 2004.

[15] Lewellen TC. Political Anthropology: An Introduction (Third Rev.). London: Praeger; 2003.

[16] Spencer J. Anthropology, Politics, and the State: Democracy and Violence in South Asia. Cambridge University Press; 2007.

[17] Messick B. The Calligraphic State: Textual Domination and History in a Muslim Society. Berkeley: University of California Press; 1993.

[18] Vom Bruck, G. Islam, Memory, and Morality in Yemen: Ruling Families in Transition. Basingstoke: Palgrave; 2005. https://doi.org/10.1007/978-1-137-11742-7

[19] Elie SD. Review of Vom Bruck, G. Islam, Memory, and Morality in Yemen: Ruling Families in Transition. Journal of the Royal Anthropological Institute 2007; 13: 1062-1063. https://doi.org/10.1111/j.1467-9655.2007.00472 36.x

[20] For details see International Social Science Council. World Social Science Report: Knowledge Divides. Paris: UNESCO Publishing; 2010.

[21] Blumi I. Destroying Yemen: What Chaos in Arabia Tells us about the World. Berkeley: University of California Press; 2018.

[22] Lackner H. Yemen in Crisis: Autocracy, Neo-Liberalism and the Disintegration of a State. London: Saqi; 2018.

[23] Hill G. Yemen Endures: Civil War, Saudi Adventurism and the Future of Arabia. London: Oxford University Press; 2017.

[24] Elie SD. The Production of Social Science Knowledge beyond Occidentalism: The Quest for a Post-Exotic Anthropology. Third World Quarterly 2012; 33 (7): 12111229.

https://doi.org/10.1080/01436597.2012.691828

[25] Elie SD. Anthropology as an Emerging Global Discipline: A New Research Ethic. Global Journal of Anthropological 
Research 2015; 2 (1): 7-29.

https://doi.org/10.15379/2410-2806.2015.02.01.02

[26] Slater D. Ordering Power: Contentious Politics and Authoritarian Leviathans in Southeast Asia. Cambridge: Cambridge University Press; 2010.

https://doi.org/10.1017/CBO9780511760891

[27] Burrowes RD. The Yemen Arab Republic: The Politics of Development, 1962-1986. Boulder, Colorado: Westview Press; 1987.

[28] Tarbush Q. Tatwir nidham al-sultat al-mahalliyya fi aljumhuriyya al-yemeniyya [Development of the Local Authority System in the Republic of Yemen]. Taiz, Yemen: Maktaba Al'Arwa Al-Wuthqa; 2003.

[29] Al-Saqqaf $A B$. The Yemeni Unity: Crisis in Integration. In: Levau R, Mermier F, Steinback U, editors. Le Yemen Contemporain. Paris: Karthala; 1999: p. 141-149.

[30] Stokey RW. Yemen: The Politics of the Yemen Arab Republic. Boulder, Colorado: Westview Press; 1978.

[31] See Al-'Ayni M. 50 Years in Shifting Sands: Personal Experience in the Building of a Modern State in Yemen. Beirut, Lebanon: Dar An-Nahar; 2004.

[32] Elie SD. Anthropology and the Encompassment of the Middle East. Anthropology of the Middle East 2010; 6(1): 103-110.

[33] See Chaudhry KA. The Price of Wealth: Economics and Institutions in the Middle East. Ithaca, NY: Cornell University Press; 1997.

[34] See Burrowes RD. The Famous Forty and their Companions: North Yemen's First-Generation Modernists and Educational Emigrants. Middle East Journal 2005; 59(1): 81-97. https://doi.org/10.3751/59.1.15

[35] For more background on the five regimes and the references used see Elie SD. State Mediation of Qāt Consumption in Yemen: The Political Socialization of the National Polity. Global Journal of Anthropology Research 2015; 2(2): 26-52. https://doi.org/10.15379/2410-2806.2015.02.02.05

[36] Smith AD. National Identity. Las Vegas: University of Nevada Press; 1991.

[37] Willis JM. Unmaking North and South: Cartographies of the Yemeni Past, 1857-1934. London: Hurst \& Company; 2012.

[38] Cannadine D. Ornamentalism: How the British Saw their Empire. London: Oxford University Press; 2002.

[39] Day SW. Regionalism and Rebellion in Yemen: A Troubled National Union. Cambridge: Cambridge University Press; 2012.

https://doi.org/10.1017/CBO9781139135443

[40] Mahoney D. Cultural Heritage and Identity Politics in Early Medieval South Arabia. In: Gingrich A, Haas S, editors. Southwest Arabia across History: Essays to the Memory of Walter Dostal. Vienna: Austrian Academy of Sciences Press; 2014: p. 67-78.

[41] See Elie SD. Regionalism in Yemen: An Effect of State Policy, not a Geographic Destiny. 2013: https://www.academia.edu/3888402

[42] Wedeen L. Peripheral Visions: Publics, Power, and Performance in Yemen. Chicago: University of Chicago Press; 2008 https://doi.org/10.7208/chicago/9780226877921.001.0001

[43] See Gellner E. Nations and Nationalism. Ithaca, NY: Cornell University Press; 1983.

[44] Hobsbawm EJ. Nations and Nationalism since 1780: Programme, Myth, Reality. Cambridge: Cambridge University Press; 1992.

[45] Halliday F. The Formation of Yemeni Nationalism: Initial Reflections. In: Jankowski J, Gershoni I, editors. Rethinking Nationalism in the Arab Middle East. New York: Columbia University Press; 1997.

[46] Bujra AS. The Politics of Stratification: A Study of Change in a South Arabian Town. Oxford: Clarendon Press; 1971.
[47] See Dawisha A. Arab Nationalism in the Twentieth Century. New Jersey: Princeton University Press; 2005.

[48] Lapidus quoted in Moaddel M. The Study of Islamic Culture and Politics: An Overview and Assessment. Annual Review of Sociology 2002; 28: 359-386.

https://doi.org/10.1146/annurev.soc.28.110601.140928

[49] See Amin S, El Kenz A. Europe and the Arab World: Patterns and Prospects for the New Relationship. New York: Zed; 2005.

[50] Hill G, Salisbury P, Northedge L, Kinninmont J. Yemen: Corruption, Capital Flight and Global Drivers of Conflict. London: Chatham House; 2013.

[51] Carapico S. Civil Society and Civil Activism in Yemen. In: Nefissa SB, Grabundzija M, Lambert J, editors. Civil Society, Associations and Local Governance in Yemen. Sanaa: Centre Français d'Archéologie et de Sciences Sociales: 2008.

https://doi.org/10.4000/books.cefas. 1446

[52] Carapico S. Civil Society in Yemen: The Political Economy of Activism in Modern Arabia. Cambridge: Cambridge University Press; 1998. https://doi.org/10.1017/CBO9780511584893

[53] World Bank. Yemen Arab Republic Local Development Associations: A New Approach to Rural Development. Washington, DC: World Bank; 1981.

[54] World Bank. Yemen Civil Society Organizations in Transition. Washington DC: World Bank; 2013.

[55] For a case study that exemplifies the above discussion of relations between the state and a tribal community see Weir S. A Tribal Order: Politics and Law in the Mountains of Yemen. Austin: University of Texas Press; 2007.

[56] See Gatter P. Politics of Qat: The Role of a Drug in Ruling Yemen. Wiesbaden: Ludwig Reichert Verlag; 2012.

[57] See National Dialogue Conference. The Comprehensive National Dialogue Conference Document, 2013-2014 (Arabic). Sana'a: Republic of Yemen; 2014.

[58] See Migdal JS. Strong Societies and Weak States: StateSociety Relations and State Capabilities in the Third World. New Jersey: Princeton University Press; 1988.

[59] Cf. Fukuyama F. Political Order and Political Decay. New York: Farrar, Straus and Giroux; 2014.

[60] Quoted from Metha PB. The Burden of Democracy. Delhi: Penguin; 2003.

[61] Transparency International, People and Corruption: Middle East and North Africa Survey. 2016. URL: www.transparency.org

[62] Ayubi NN. Over-Stating the Arab State: Politics and Society in the Middle East. London: I.B. Tauris; 1995

[63] World Bank. The Republic of Yemen: Unlocking the Potential for Economic Growth. Washington, DC: World Bank; 2015.

[64] Nasser A. and Harper AJ. Rapid Currency Depreciation and the Devaluation of Yemeni Purchasing Power. Sana'a, Yemen: Sana'a Center for Strategic Studies; March 2017.

[65] International Monetary Fund. Republic of Yemen 2013 Article IV Consultation. Country Report No. 13/246. Washington, DC: IMF; July 2013.

[66] Yemen Polling Center. Yemeni Citizens' Main Concerns, Perception of Human Rights and CSOs. Sanaa: Yemen; September 2012.

[67] Alley AL. The Rules of the Game: Unpacking Patronage Politics in Yemen. Middle East Journal 2010; 64: 385-409. https://doi.org/10.3751/64.3.13

[68] Phillips S. Yemen: Developmental Dysfunction and Division in a Crisis State. Developmental Leadership Programme Research Paper 14; 2011.

[69] Lackner H, Ed. Why Yemen Matters: A Society in Transition. London: Saqi; 2014. 
[70] International Crisis Group (ICG). Yemen's Southern Question: Avoiding a Breakdown. Brussels: Middle East Report No. 145; September 2013.

[71] Brandt M. Tribes and Politics in Yemen: A History of the Houthi Conflict. London: Oxford University Press; 2017. https://doi.org/10.1093/oso/9780190673598.001.0001

[72] See Bonnefoy L. Politics and the Islamists in the Yemeni Revolution. In: Lackner $\mathrm{H}$, editor. Why Yemen Matters: A Society in Transition. London: Saqi; 2014: p. 87-104.

[73] Schmitz C. Yemen's National Dialogue. Washington DC: Middle East Institute; 2014.

[74] Baron A. The Politics Driving Yemen's Rising Sectarianism. Yemen: Sana'a Center For Strategic Studies, May 2016. URL: publications $/ 40$.

[75] Albloshi HH. Ideological Roots of the Hūthī Movement in Yemen. Journal of Arabian Studies 2016; 6(2): 143-162. https://doi.org/10.1080/21534764.2016.1247522
[76] See Al-Muslimi F. How Sunni-Shia Sectarianism is Poisoning Yemen. Diwan. Carnegie Middle East Center; December 29, 2015. URL: http://carnegiemec.org/diwan/62375?lang=en.

[77] National Dialogue Conference. Final Communiqué of the National Dialogue Conference. Sana'a: Republic of Yemen; 2014.

[78] Douglas JL. The Free Yemeni Movement 1935-1963. Beirut, Lebanon: American University Press; 1987.

[79] See Yadav SP, and Carapico S. The Breakdown of the GCC Initiative. Middle East Report 2014; 273: 2-6.

[80] See Williams P, Sommadossi T, Mujais A. A Legal Perspective on Yemen's Attempted Transition from a Unitary to a Federal System of Government. Utrecht Journal of International and European Law 2017; 33: 4-22. https://doi.org/10.5334/uiiel.366

(c) 2018 Serge D. Elie; Licensee Cosmos Scholars Publishing House.

This is an open access article licensed under the terms of the Creative Commons Attribution Non-Commercial License

(http://creativecommons.org/licenses/by-nc/3.0/), which permits unrestricted, non-commercial use, distribution and reproduction in any medium, provided the work is properly cited. 